\title{
PROTEÇÃO AMBIENTAL E FUTURAS GERAÇÕES: UMA ANÁLISE DA POSIÇÃO DO SUPERIOR TRIBUNAL DE JUSTIÇA
}

\author{
ENVIRONMENTAL PROTECTION AND FUTURE GENERATIONS: AN ANALYSIS OF THE \\ POSITION OF THE SUPERIOR COURT OF JUSTICE
}

\begin{abstract}
Jéssica Garcia da Silva Maciel
Pós-graduanda em Direito Público na Escola Superior da Magistratura Federal (ESMAFE). Graduada em Direito pela Universidade de Caxias do Sul (UCS). Pesquisadora do Grupo de pesquisa "Cultura Política, Políticas Públicas e Sociais". Advogada. Conciliadora Judicial Voluntária do Tribunal Regional Federal da $4^{\mathrm{a}}$ Região.

Email: jgsmaciel@ucs.br

Leonardo da Rocha de Souza

Pós-doutor, Doutor e Mestre em Direito pela Universidade Federal do Rio Grande do Sul (UFRGS);

Bacharel em Direito pela Universidade do Vale do Rio dos Sinos (UNISINOS); Licenciado em Ciências Sociais (ULBRA). Especialista em Ética e Filosofia Política (UCS);

Professor Efetivo da Universidade Regional de Blumenau (FURB);

Vice-líder do grupo de pesquisa CNPq/FURB 'Direitos Fundamentais, Cidadania e Justiça'; Professor Adjunto da Universidade de Caxias do Sul.

E-mail: leorochasouza@gmail.com
\end{abstract}

Recebido em: 01/08/2018

Aprovado em: 13/12/2018

RESUMO: A necessidade de garantir às futuras gerações o acesso equitativo ao meio ambiente exige a aplicação de princípios como in dubio pro natura e da equidade intergeracional. Porém, esses princípios podem ser aplicados sem a devida precisão, ocasionando a existência de riscos irreversíveis provenientes de equívocos na sua interpretação e aplicação. O objetivo desta pesquisa é verificar de que forma o Superior Tribunal de Justiça interpreta e aplica o direito ambiental em suas decisões quando o assunto envolve as futuras gerações. Adota-se o método indutivo, partindo da análise de casos (particular) para descobrir o entendimento do tribunal analisado (geral) por meio da análise de conteúdo das decisões judiciais. Como resultado, percebe-se que o Superior Tribunal de Justiça tem demonstrado preocupação com as futuras gerações. Surgiu a dificuldade, no entanto, de verificar se as futuras gerações são protegidas em outras decisões nas quais a expressão "futuras gerações" deixam de ser mencionadas. Essa dificuldade aponta para uma sequência de possíveis pesquisas a serem realizadas.

Palavras-chave: Futuras Gerações; Meio ambiente; Gestão Ambiental; Sustentabilidade. 
ABSTRACT: The need to ensure equitable access to the environment for future generations requires the application of principles such as in dubio pro natura and intergenerational equity. However, these principles can be applied without due precision, causing the existence of irreversible risks arising from misunderstandings in their interpretation and application. The purpose of this research is to verify how the brazilian Superior Court of Justice interprets and applies environmental law in its decisions when the matter involves future generations. The inductive method is adopted, starting from the analysis of cases (specific) to discover the understanding of the analyzed court (general) through the analysis of the content of the judicial decisions. As a result, it can be seen that the Superior Court of Justice has shown concern for future generations. The difficulty has arisen, however, to verify whether future generations are protected in other decisions in which the term "future generations" is no longer mentioned. This difficulty points to a sequence of possible researches to be carried out.

Keywords: Future Generations; Environment; Environmental management; Sustainability.

SUMÁRIO: Introdução; 1 Proteção ambiental e futuras gerações; 2 Análise da posição do Superior Tribunal de Justiça em decisões envolvendo futuras gerações; 2.1 Metodologia; 2.2 Análise Das Decisões; 2.2.1 Patrimônio Cultural; 2.2.2 Áreas de Preservação Permanente e Reserva Legal; 2.2.3 Responsabilidade civil por danos ambientais; 2.2.4 Competência; Considerações Finais; Referências.

\section{INTRODUÇÃO}

Diante complexidade que envolve o bem ambiental, sua proteção tem sido cada vez mais judicializada, o que exige do magistrado que atua nessa área um constante exercício de interpretação e aplicação do direito ambiental, buscando-se garantir às futuras gerações o acesso equitativo ao meio ambiente. Essa realidade aponta para a necessidade de verificar como o Poder Judiciário tem protegido os interesses ambientais das futuras gerações. Nesse sentido, fazendo-se um recorte da resposta judiciária a um dos mais importantes tribunais, o presente artigo busca responder ao seguinte problema de pesquisa: que parâmetros são adotados pelo Superior Tribunal de Justiça que permitam a proteção do meio ambiente para as futuras gerações?

Uma primeira hipótese é a aplicação dos princípios in dubio pro natura e da equidade intergeracional. Porém, esses princípios podem ser aplicados sem a devida precisão ocasionando a existência de riscos irreversíveis. É possível, assim, que haja eventuais enganos jurídicos na sua interpretação e aplicação. Com o intuito de bem conservar o sistema ecológico mundial, vital para a preservação das gerações atuais e futuras, e tendo em vista que muitos dos recursos disponíveis na natureza são finitos, é importante analisar eventuais contrassensos jurídicos na interpretação e na aplicação desse princípio.

Uma segunda hipótese, seria a imprescritibilidade da reparação de danos ambientais. Com a efetiva ocorrência de danos ambientais, estaria o magistrado observando a prerrogativa da imprescritibilidade das ações que visam o retorno do meio ambiente ao status quo ante? Em algumas situações, a aplicação dessa prerrogativa pode ser ignorada.

Adota-se o método indutivo, partindo da análise de casos (particular) para descobrir-se o entendimento do tribunal analisado (geral) por meio da análise jurisprudencial acerca da preservação do meio ambiente às futuras gerações no Superior Tribunal de Justiça. Para 
desenvolver o trabalho, realiza-se breve pesquisa bibliográfica a partir de referenciais teóricos que indicam parâmetros de proteção ambiental em favor das futuras gerações (2). O tópico seguinte partirá para a pesquisa empírica, analisando dados presentes nas decisões do Superior Tribunal de Justiça (3).

A pesquisa de decisões permitirá chegar a conclusões sobre quais elementos são usados pelo STJ para garantia de um meio ambiente ecologicamente equilibrado e sadio, apto a garantir a qualidade de vida das futuras gerações e o quanto ainda falta avançar para que esse grupo se torne efetivamente importante nas decisões ambientais.

\section{PROTEÇÃO AMBIENTAL E FUTURAS GERAÇÕES}

As intervenções humanas sobre o meio ambiente estão colocando em risco a diversidade da fauna e da flora existentes na Terra, tendo como consequência o desequilíbrio dos ecossistemas. Ações como a derrubada de florestas para atividades de agricultura e pecuária ameaçam o solo, a água e a atmosfera. Apesar da grande quantidade de informações, "Todo o vasto conhecimento existente tem se revelado extremamente insuficiente para influir no comportamento humano, em sua lógica depredadora e consumista e no verdadeiro descaso com o futuro da espécie e do planeta". 1

A Declaração do Rio de Janeiro, sobre Meio Ambiente e Desenvolvimento, elaborada na Rio 92, garante às futuras e presentes gerações o direito ao meio ambiente ecologicamente equilibrado através do princípio 3, que propõe: “O direito ao desenvolvimento deve ser exercido de modo a permitir que sejam atendidas equitativamente as necessidades de desenvolvimento e de meio ambiente das gerações presentes e futuras". ${ }^{2}$ Do mesmo modo, prevê a Declaração de Estocolmo de 1972, em seu princípio 2: "Os recursos naturais da Terra, incluídos o ar, a água, o solo, a flora e a fauna e, especialmente, parcelas representativas dos ecossistemas naturais, devem ser preservados em benefício das gerações atuais e futuras". ${ }^{3}$

O princípio fundamental da dignidade da pessoa humana previsto no artigo $1^{\circ}$, III, da Constituição Federal, prevê esse paralelismo entre os direitos das presentes e das futuras gerações, vez que há de ser sustentado todo o patrimônio ambiental e cultural em prol das garantias fundamentais do ser humano.

\footnotetext{
Essas relações não ocorrem entre presentes, mas entre pessoas que, embora não convivam na mesma realidade temporal, têm um direito em comum, a dignidade humana, cuja realização depende das conservações das opções, da preservação da qualidade do planeta e da manutenção do acesso aos bens naturais. Mesmo que não haja um relacionamento recíproco entre as gerações, elas têm um ponto de contato, algo que as une e que equaliza seus membros: o meio ambiente. ${ }^{4}$
}

O direito das gerações futuras é assegurado por leis nacionais e internacionais, entretanto, o desenvolvimento para evolução da sociedade atual acarreta desequilíbrio ambiental. Ao passo

\footnotetext{
${ }^{1}$ SOUZA, Leonardo da Rocha de. A Consideração dos Ausentes à Deliberação Ambiental: Uma proposta a partir da Ética do Discurso de Jürgen Habermas, p. 143, com base nos ensinamentos de Carlos André Birnfeld, Cidadania Ecológica, p. 70-71.

${ }^{2}$ Declaração do Rio de Janeiro, sobre Meio Ambiente e Desenvolvimento (1992), p. 1137.

${ }^{3}$ Declaração de Estocolmo sobre o Meio Ambiente Humano (1972), p. 1134.

${ }^{4}$ SOUZA, Leonardo da Rocha de. A Consideração dos Ausentes à Deliberação Ambiental: Uma proposta a partir da Ética do Discurso de Jürgen Habermas, p. 145.
} 
que a ciência e as tecnologias tomam lugar no mundo para melhorar as condições de vida dos indivíduos, esses sentem seus direitos individuais ameaçados, pois, para criação de inovações tecnológicas, muitas vezes, é preciso de recursos naturais esgotáveis. Além disso, tem-se a biotecnologia que usa organismos vivos para a produção de bens e serviços e aumenta o consumismo já desenfreado, ou seja, a natureza está sendo manipulada com o propósito de captar lucro, ameaçando mais uma vez a humanidade. ${ }^{5}$

O desenvolvimento sustentável que se propagou nas últimas décadas tornou o ser humano consciente de seus atos para com a natureza. Não obstante, é preciso considerar de que forma as ações do ser humano estão refletindo no mundo físico para que assim os problemas sejam corrigidos.

A Constituição Federal do Brasil (art. 225) garante que todos (presentes e futuras gerações) têm direito ao meio ambiente ecologicamente equilibrado e cabe a todos sua preservação. As normas jurídicas exercem poder sobre o âmbito político, financeiro, socioambiental e ecológico, contudo, apesar de notáveis os esforços do legislador, o cumprimento de tais normas nem sempre é efetivo. O Estado preocupa-se em contentar os interesses opostos dos grupos em conflito gerando constantemente uma insegurança jurídica. Apesar de o Direito ter um campo específico para o meio ambiente (o Direito Ambiental), o futuro ecológico corre o risco de ser cada vez mais guiado pelo sistema econômico. Logo, o sistema jurídico só não basta para solucionar as controvérsias acerca da situação do ecossistema ${ }^{6}$.

Ademais, deve-se levar em conta que a insuficiência de recursos humanos e os erros processuais acarretam na diminuição da eficácia nos processos relacionados a danos ambientais. Assim, deve-se limitar, através da segurança estatal, a intervenção humana sobre a natureza, pois qualquer erro pode castigar irreversivelmente as gerações futuras. A coletividade atual é caracterizada pela incerteza e pelo risco, que geram efeitos e vítimas que nem sempre podem ser determinados cientificamente. Nesse contexto de risco mundial é o meio jurídico que protege o povo $^{7}$. No entanto, o ordenamento jurídico-ambiental é historicamente recente e as políticas públicas realizadas a favor do meio ambiente ainda não suprem o imensurável dano ambiental criado do passado até hoje.

Necessária se faz a análise do princípio da equidade intergeracional, que prevê solidariedade e inclusão das futuras gerações na proteção ambiental. A justiça e a sustentabilidade são termos que não se separam. A sustentabilidade é a continuação do meio ambiente ou das espécies sem interferir no direito que as gerações futuras também têm a um meio ambiente em condições ao menos iguais àquelas que se dispõe hoje.

Em relação aos bens ambientais, tem-se reconhecido que um limite foi atingido, a ponto de a interferência das presentes gerações ameaçar a expectativa de direitos de futuras gerações. Desse modo, aflora a necessidade de examinar qual a relação de responsabilidade estabelecida do presente para com o futuro. Para esta questão é preciso transcender o limite temporal, além do tempo presente, uma solidariedade intergeracional que considere os interesses e os direitos das gerações atuais e futuras.

Assim, tendo em vista que o direito é um instrumento estabilizador dessa problemática e diante da constante judicialização de temas relacionados à proteção ambiental, aumenta o interesse

\footnotetext{
${ }^{5}$ SCHIOCCHET, Taysa; LIEDKE, Mônica Souza. O direito e a proteção das gerações futuras na sociedade de risco global. Veredas do Direito, Belo Horizonte, 2012, v.9, n. 17, p. 111-112.

${ }^{6}$ SCHIOCCHET, Taysa; LIEDKE, Mônica Souza. O direito e a proteção das gerações futuras na sociedade de risco global, p. 121.

${ }^{7}$ SCHIOCCHET, Taysa; LIEDKE, Mônica Souza. O direito e a proteção das gerações futuras na sociedade de risco global, p. 128.
} 
em verificar como o Poder Judiciário tem tratado esse tema e protegido os interesses das futuras gerações, o que será abordado no restante deste artigo.

\section{ANÁLISE DA POSIÇÃO DO SUPERIOR TRIBUNAL DE JUSTIÇA EM DECISÕES ENVOLVENDO FUTURAS GERAÇÕES}

Neste tópico realiza-se uma apresentação da metodologia utilizada para análise das decisões encontradas com o termo "futuras gerações" no site do Superior Tribunal de Justiça (3.1) e, após, parte-se para uma análise das decisões agrupadas por assunto (3.2).

\subsection{Metodologia}

O Superior Tribunal de Justiça (STJ) tem se destacado nas decisões que envolvem o Direito Ambiental. Por ser um tribunal de alçada superior, suas decisões são tidas como referenciais para a primeira e segunda instâncias, bem como para a formação legislativa e doutrinária do Direito. Buscando uma aplicação mais equânime e justa, o STJ tem se utilizado de princípios para integrar normas a casos concretos, especialmente no Direito Ambiental.

Este tópicos se dedica a apresentar as decisões e as respectivas análises de como, em quais situações e sob que fundamento os direitos das futuras gerações vêm sendo garantidos no âmbito do Superior Tribunal de Justiça. Salo de Carvalho ${ }^{8}$ afirma que além de abrir possibilidades, os estudos de caso rompem com a lógica que limita a pesquisa científica à mera revisão bibliográfica e ainda fornecem perspectivas inovadoras para a academia jurídica nacional.

O instrumento utilizado para esta pesquisa foi a ferramenta "Pesquisa de Jurisprudência" disponibilizada no sítio de internet do STJ (http://www.stj.jus.br/SCON/), no dia 19 de março de 2018, tendo utilizado como termo de referência no campo "Pesquisa Livre" as palavras [futuras gerações], tendo sido encontrados um total de 51 (cinquenta e um) documentos. A busca objetivou os acórdãos proferidos pelo STJ. Desses documentos, sete ${ }^{9}$ são decisões de Direito Penal, proferidas pela Quinta e Sexta Turmas da Corte, uma ${ }^{10}$ é de Direito de Família, proferida pela

\footnotetext{
${ }^{8}$ CARVALHO, Salo de. Como (não) se faz um trabalho de conclusão: provocações úteis para orientadores $e$ estudantes de direito. 2. ed. São Paulo: Saraiva, 2013.p. 52.

${ }^{9}$ BRASIL. Superior Tribunal de Justiça. RHC 64039/RS, Relator: Min. Ribeiro Dantas, Quinta Turma, julgado em 24/05/2016, DJ-e 03/06/2016.

BRASIL. Superior Tribunal de Justiça. RHC 64219/MS, Relator: Min. Reynaldo Soares da Fonseca, Quinta Turma, julgado em 17/03/2016, DJ-e 30/03/2016.

BRASIL. Superior Tribunal de Justiça. RHC 64124/MS, Relator: Min. Reynaldo Soares da Fonseca, Quinta Turma, julgado em 17/03/2016, DJ-e 30/03/2016.

BRASIL. Superior Tribunal de Justiça. AgRg no REsp 1558576/PR, Relator: Min. Sebastião Reis Júnior, Sexta Turma, julgado em 01/03/2016, DJ-e 17/03/2016.

BRASIL. Superior Tribunal de Justiça. HC 238344/PA, Relator: Min. Sebastião Reis Júnior, Sexta Turma, julgado em 15/08/2013, DJ-e 06/09/2013.

BRASIL. Superior Tribunal de Justiça. REsp 897426/SP, Relatora: Min. Laurita Vaz, Quinta Turma, julgado em 27/03/2008, DJ-e 28/04/2008.

BRASIL. Superior Tribunal de Justiça. HC 72234/PE, Relator: Min. Napoleão Nunes Maia Filho, Quinta Turma, julgado em 09/10/2007, DJ 05/11/2007, p. $307 .$.

${ }_{10}$ BRASIL. Superior Tribunal de Justiça. REsp 876434/RS, Relator: Min. Raul Araújo, Quarta Turma, julgado em 01/12/2011, DJ-e 01/02/2012.
} 
Quarta Turma da Corte e uma ${ }^{11}$ é de Direito do Consumidor, proferida pela Corte Especial. Por não estarem relacionadas ao tema deste trabalho, as sete decisões de Direito Penal, a decisão de Direito de Família e a decisão de Direito do Consumidor não foram analisadas. Dos quarenta e dois documentos restantes, trinta e dois são Recursos Especiais, quatro são Agravos Regimentais em Recurso Especial, três são Recursos Ordinários em Mandado de Segurança, um é Agravo Regimental no Agravo de Instrumento, um é Agravo Regimental no Agravo em Recurso Especial e um é Agravo Interno no Agravo em Recurso Especial.

Dessas quarenta e duas decisões que contêm a expressão "futuras gerações", treze ${ }^{12}$ não tratam efetivamente das futuras gerações dentro dos votos, fazendo, por vezes, menção às futuras gerações dentro de alguns conceitos doutrinários, ou em algumas ementas citadas nas decisões, sem aprofundamento. Restam, assim, 29 decisões efetivamente analisadas nesta pesquisa.

Nos critérios de pesquisa não foi delimitado um lapso temporal, mas o primeiro julgamento referente à busca ocorreu em 17/02/2004 e o último em 19/09/2017, chegando a um período de treze anos de utilização do termo futuras gerações. Além disso, deixa-se de abordar questões processuais, atendo-se às questões materiais que envolvam as futuras gerações.

\subsection{Análise das Decisões}

Para uma análise mais didática, as decisões que envolvam a expressão "futuras gerações" são agrupadas por assunto, dividindo-se nos seguintes subcapítulos: (3.2.1) Patrimônio cultural; (3.2.2) Áreas de preservação permanente e reserva legal; (3.2.3) Responsabilidade civil por danos ambientais; e (3.2.4) Competência. As informações sobre o processo em primeiro e segundo grau,

\footnotetext{
${ }^{11}$ BRASIL. Superior Tribunal de Justiça. EREsp 1192577/RS, Relatora: Min. Laurita Vaz, Corte Especial, julgado em 21/10/2015, DJ-e 13/11/2015.

12 BRASIL. Superior Tribunal de Justiça. AgInt no AREsp 1060669/SP, Relator: Min. Herman Benjamin, Segunda Turma, julgado em 19/09/2017, DJ-e 09/10/2017.

BRASIL. Superior Tribunal de Justiça. REsp 1616027/SP, Relator: Min. Herman Benjamin, Segunda Turma, julgado em 14/03/2017, DJ-e 05/05/2017.

BRASIL. Superior Tribunal de Justiça. AgRg no AREsp 13188/ES, Relator: Min. Sergio Kukina, Primeira Turma, julgado em 14/06/2016, DJ-e 24/06/2016.

BRASIL. Superior Tribunal de Justiça. AgRg no REsp 1356449/TO, Relator: Min. Herman Benjamin, Segunda Turma, julgado em 03/05/2016, DJ-e 25/05/2016.

BRASIL. Superior Tribunal de Justiça. AgRg 1352664/RJ, Relator: Min. Mauro Campbell Marques, Segunda Turma, julgado em 14/05/2013, DJ-e 20/05/2013.

BRASIL. Superior Tribunal de Justiça. AgRg 1238089/RS, Relator: Min. Humberto Martins, Segunda Turma, julgado em 24/05/2011, DJ-e 01/06/2011.

BRASIL. Superior Tribunal de Justiça. REsp 302906/SP, Relator: Min. Herman Benjamin, Segunda Turma, julgado em 26/08/2010, DJ-e 01/12/2010.

BRASIL. Superior Tribunal de Justiça. REsp 1135807/RS, Relator: Min. Herman Benjamin, Segunda Turma, julgado em 15/04/2010, DJ-e 08/03/2012.

BRASIL. Superior Tribunal de Justiça. REsp 1137314/MG, Relator: Min. Herman Benjamin, Segunda Turma, julgado em 17/11/2009, DJ-e 04/05/2011.

BRASIL. Superior Tribunal de Justiça. RMS 18107/RJ, Relator: Min. Herman Benjamin, Segunda Turma, julgado em 25/08/2009, DJ-e 04/05/2011.

BRASIL. Superior Tribunal de Justiça. REsp 1103923/SC, Relator: Min. Herman Benjamin, Segunda Turma, julgado em 20/08/2009, DJ-e 24/04/2011.

BRASIL. Superior Tribunal de Justiça. REsp 853713/SP, Relator: Min. Herman Benjamin, Segunda Turma, julgado em 06/08/2009, DJ-e 27/04/2011.

BRASIL. Superior Tribunal de Justiça. REsp 588022/SC, Relator: Min. José Delgado, Primeira Turma, julgado em 17/02/2004, DJ 05/04/2004, p. 217.
} 
partes, objeto da ação, citações, posição dos ministros e resultado, são provenientes do acórdão, em especial do relatório e do voto dos Ministros Relatores.

\subsubsection{Patrimônio cultural}

Este subcapítulo tem como delimitação de tema decisões que envolvam patrimônio cultural, temática prevista no art. 216 da Constituição Federal. Para Paulo Affonso Leme Machado o patrimônio cultural representa:

[...] o trabalho, a criatividade, a espiritualidade e as crenças, o cotidiano e o extraordinário de gerações anteriores, diante do qual a geração presente terá que emitir um juízo de valor, dizendo o que quererá conservar, modificar ou até demolir. Esse patrimônio é recebido sem mérito da geração que o recebe, mas não continuará a existir sem seu apoio. $\mathrm{O}$ patrimônio cultural deve ser fruído pela geração presente, sem prejudicar a possibilidade de fruição da geração futura. ${ }^{13}$

Um dos instrumentos jurídicos que protege e conserva o patrimônio brasileiro é o tombamento, que permite efetivar a função social da propriedade "tendo em vista seus aspectos históricos, artísticos, naturais, paisagísticos e outros relacionados à cultura, para a fruição das presentes e futuras gerações". ${ }^{14} \mathrm{O}$ objetivo do tombamento é evitar ações ou omissões que comprometam a herança coletiva e intergeracional do patrimônio ancestral e nada menos do que recebeu das gerações passadas seja deixado às próximas gerações. Desse modo, passa-se à análise das decisões que utilizam-se do tombamento para conservar o patrimônio cultural e assegurar às futuras gerações o senso de igualdade intergeracional.

O Recurso Especial n ${ }^{0}$ 1.293.608/PE ${ }^{15}$ de relatoria do Ministro Herman Benjamin, tem por recorrente Maria do Carmo Martins de Souza e por recorrido Município de Olinda. Em Ação Demolitória proposta pelo Município de Olinda, o Município alega ofensa à legislação incidente sobre o patrimônio cultural em relação à reforma de um imóvel feita pela recorrente e, ainda, que após a reforma a estrutura do imóvel não estaria em acordo com as disposições relativas à preservação do sítio histórico.

O Relator, Ministro Herman Benjamin, em seu voto, defende o tombamento e outras formas de intervenção na propriedade, não somente para proteger obras grandiosas e de estética refinada, mas também os feitos e sofrimentos daqueles que foram estigmatizados, "para que deles, do seu exemplo, coragem e adversidade nunca se olvidem as gerações futuras, fazem jus igualmente à preservação seus monumentos, conjuntos e locais de interesse, com suas peculiares marcas arquitetônicas, mesmo que modestas e carentes de ostentação", e, em relação aos bens imateriais, também com a proteção de "seus rituais, manifestações culturais, raízes etnológicas ou antropológicas, e até espaços de indignidade e desumanidade - do calabouço à senzala, da sala de tortura ao campo de concentração", até mesmo para não "comprometer a herança coletiva e intergeracional do patrimônio ancestral, seja ele tombado ou não, monumental ou não".

Nesse ponto, o Relator destaca o poder geral de cautela que, se não utilizado no momento certo, "nunca passará de imitação do passado ou da Natureza, caricatura da História ou dos

\footnotetext{
${ }^{13}$ MACHADO, Paulo Affonso Leme. Direito Ambiental Brasileiro. São Paulo: Editora Malheiros, 2014, p. 10941095.

${ }^{14}$ MACHADO, Paulo Affonso Leme. Direito Ambiental Brasileiro, p. 1114-1115.

15 BRASIL. Superior Tribunal de Justiça. REsp 1293608/PE, Relator: Min. Herman Benjamin, Segunda Turma, julgado em 04/12/2012, DJ-e 11/09/2014.
} 
processos ecológicos e geológicos que pretende substituir”.

Tanto em decisões cautelares e antecipações de tutela, como em juízos de mérito, esperase do juiz jamais se esquecer de cuidadosamente apurar e ponderar o "periculum in mora reverso", a contraposição - sob o teste quíntuplo dos sujeitos envolvidos, do valor do bem, da disponibilidade do bem, da fungibilidade do bem e da reparabilidade do dano - entre interesse individual e interesse coletivo; interesse atual do indivíduo e interesse prospectivo das gerações futuras; interesse patrimonial disponível e interesse indisponível associado à dignidade da pessoa humana e a bens indisponíveis; interesse financeiro ou monetário ressarcível e interesse intangível irreparável ou de difícil reparação.

Conclui que "a degradação ou o desaparecimento de um bem cultural e natural acarreta o empobrecimento irreversivel do patrimônio de todos os povos do mundo"16. Por fim, conheceu parcialmente do Recurso Especial e, nessa parte, por unanimidade, negou-se provimento.

O Recurso Especial $n^{\circ} 808.708 / \mathrm{RJ}^{17}$, também de relatoria do Ministro Herman Benjamin, tem por recorrente Dagmar Gonçalves da Fonseca e por recorrida a União Federal. A recorrente é viúva de servidor público que construiu sua casa no Jardim Botânico do Rio de Janeiro na década de 1950. Discute-se, na hipótese, o direito de indenização por imóvel construído no Jardim Botânico do Rio de Janeiro. O Tribunal de origem entendeu ser inviável a posse de área pública, e juridicamente impossível, portanto, o pleito de indenização pelas benfeitorias. Fundado em 1808 por Dom João VI, o Jardim Botânico do Rio de Janeiro é um dos tesouros do patrimônio natural, histórico, cultural e paisagístico do Brasil, de fama internacional, tendo sido um dos primeiros bens tombados, ainda em 1937, pelo Instituto do Patrimônio Histórico e Artístico Nacional (IPHAN), sob o pálio do então recém-promulgado Decreto-Lei no 25/1937.

Nas palavras do Ministro Relator, sobre a tolerância ou omissão do servidor público:

[...] a história fundiária do Brasil, tanto no campo como na cidade, está, infelizmente até os dias atuais, baseada na indevida apropriação privada dos espaços públicos, com freqüência às claras e, mais grave, até com estímulo censurável, tanto por ação como por leniência, de servidores públicos, precisamente aqueles que deveriam zelar, de maneira intransigente, pela integridade e longevidade do patrimônio nacional.

Além de rasgar a Constituição e humilhar o Estado de Direito, substituindo-o, com emprego de força ou manobras jurídicas, pela "lei da selva", a privatização ilegal de espaços públicos, notadamente de bens tombados ou especialmente protegidos, dilapida o patrimônio da sociedade e compromete o seu gozo pelas gerações futuras.

E, também, sobre o Jardim Botânico como bem público tombado:

O Estado pode - e deve - amparar aqueles que não têm casa própria, seja com a construção de habitações dignas a preços módicos, seja com a doação pura e simples de residência às pessoas que não podem por elas pagar. É para isso que existem Políticas Públicas de Habitação federais, estaduais e municipais. O que não se mostra razoável é torcer as normas que regram a posse e a propriedade pública para atingir tais objetivos sociais e, com isso, acabar por dar tratamento idêntico a todos (necessitados e abastados) os que se encontram na mesma posição de ocupantes ilegais do que pertence à comunidade e às gerações futuras.

\footnotetext{
${ }^{16}$ Preâmbulo da Convenção Relativa à Proteção do Patrimônio Mundial, Cultural e Natural, adotada em Paris em 16 de novembro de 1972, com entrada em vigor, no Brasil, em 2 de dezembro de 1977.

${ }^{17}$ BRASIL. Superior Tribunal de Justiça. REsp 808708/RJ, Relator: Min. Herman Benjamin, Segunda Turma, julgado em 18/08/2009, DJ-e 04/05/2011.
} 
O Relator reconhece que a crise habitacional não será resolvida com o aniquilamento do patrimônio histórico-cultural nacional: “[...] destruí-lo a pretexto de dar casa e abrigo a uns poucos corresponde a deixar milhões de outros sem teto e, ao mesmo tempo, sem a memória e a herança do passado para narrar e passar a seus descendentes."

Quanto a eventual indenização, dispõe que deve ser buscada após a desocupação do imóvel, momento em que o Poder Público terá a oportunidade de cobrar-lhe pelo período em que ocupou o imóvel, despesas com a demolição e danos à coletividade e ao próprio bem. "Inexiste boa-fé contra expressa determinação legal. Ao revés, entende-se agir de má-fé o particular que, sem título expresso, inequívoco, válido e atual ocupa imóvel público, mesmo depois de notificação para abandoná-lo, situação típica de esbulho permanente, em que cabível a imediata reintegração judicial.” Por unanimidade, negou-se provimento ao Recurso Especial.

O Recurso Especial $\mathrm{n}^{0}$ 840.918/DF ${ }^{18}$ teve a relatoria da Ministra Eliana Calmon e relatoria para acórdão do Ministro Herman Benjamin, tendo por recorrente Ministério Público Federal e por recorrido o Distrito Federal. Cuida-se, na origem, de Ação Civil Pública contra o Distrito Federal proposta pelo Instituto do Patrimônio Histórico e Artístico Nacional (IPHAN), órgão federal responsável pela preservação do acervo patrimonial, tangível e intangível, dos bens notáveis pelo que representam da nossa história e cultura. E versa sobre o gradeamento da área comum do piso inferior dos edifícios residenciais das superquadras, que, composto de pilotis, deveria permanecer aberto e livre ao trânsito de pessoas, moradores ou não. O recorrente alega que a instalação de grades em volta dos pilotis dos blocos de apartamentos infringe o art. 17 do Decreto-Lei n ${ }^{\circ}$ 25/1937, haja vista o tombamento do plano-piloto de Brasília e a falta de autorização do órgão do patrimônio histórico para a realização da obra.

O plano-piloto de Brasília foi tombado pelo Iphan em $1990^{19}$. Além disso, em 1987 a UNESCO reconheceu Brasília como patrimônio mundial, no contexto da Convenção Relativa à Proteção do Patrimônio Mundial, Cultural e Natural ${ }^{20}$. Segundo a Convenção, os Estados-Parte reconhecem que lhes cabe "a obrigação de identificar, proteger, conservar, valorizar e transmitir às futuras gerações" o seu patrimônio cultural e natural e que deverão "tudo fazer para esse fim" (art. $\left.4^{\circ}\right)$.

Na hipótese, verifica-se que pretendeu-se no projeto de Brasília atenuar o isolamento percebido em outras metrópoles e garantir ao coletivo um espaço de convivência. Sendo assim, o gradeamento, além de violar o art. 17 do Decreto-Lei 25/1937, mutila o projeto original tombado.

Nas palavras do Ministro Herman Benjamin:

O grave problema da violência urbana, que assola e amedronta as nossas cidades, não legitima o comprometimento do patrimônio cultural brasileiro, nem autoriza a apropriação privada de espaços públicos. Segurança pública é alcançada com maior e melhor policiamento, associado a programas de inclusão social, e não com ofensa a outros bens e interesses coletivos, notadamente aqueles de que também são titulares as gerações futuras. Brasília fez a escolha de ser livre nos seus espaços arquitetônicos e paisagísticos. Para continuar a ser o que é ou o que deveria ser, precisa controlar o individualismo, a liberdade de construir onde e como se queira, e a ênfase de seus governantes no curto-prazo, que tende a sacrificar o patrimônio público imaterial, o belo, o histórico e, portanto, os

\footnotetext{
${ }^{18}$ BRASIL. Superior Tribunal de Justiça. REsp 840918/DF, Relatora: Min. Eliana Calmon, Relator para Acórdão: Min. Herman Benjamin, Segunda Turma, julgado em 14/10/2008, DJ-e 10/09/2010.

${ }^{19}$ Nos termos do Decreto-Lei n ${ }^{\circ} 25$, de 30 de novembro de 1937, estatuto federal que protege o patrimônio histórico e artístico nacional.

${ }^{20}$ Adotada em Paris em 16 de novembro de 1972 e que entrou em vigor, no Brasil, em 2 de dezembro de 1977.
} 
interesses das gerações futuras.

Recurso Especial, por maioria, provido para reconhecer que o Distrito Federal violou o art. 17 do Decreto-Lei ${ }^{\circ} 25 / 1937$ ao permitir o cercamento.

O Recurso Especial n ${ }^{\mathrm{o}}$ 1.359.534/MA ${ }^{21}$, de relatoria do Ministro Herman Benjamin, tem por recorrente a CONAN (Companhia de Navegação do Norte) e por recorrido o Ministério Público do Estado do Maranhão. Trata-se de obrigação de fazer em relação a dois imóveis tombados no centro de São Luís, Maranhão. O acórdão recorrido justifica, com base no Decreto Estadual $\mathrm{n}^{\circ}$ 10.089/1986, que são responsáveis solidariamente pela situação de imóvel urbano em situação de risco, face o abandono e descaso e pelos danos causados ao patrimônio histórico e cultural, o proprietário, o Estado e o Município. Analisa o Relator que, em tal caso, a omissão desidiosa, a omissão de zelo, traz periculosidade maior ao bem quanto à prática de atos comissivos de degradação, pois "leva à destruição do patrimônio de maneira gradual, em lenta agonia, o que, no mais das vezes, dificulta a percepção e o controle pelo Estado e da sociedade, que ao perceberem o estrago, já é tarde demais".

Nessa linha de entendimento, [argumenta o Relator] tem-se que, como emanação da função memorativa do direito de propriedade, o tombamento, voluntário ou compulsório, produz três órbitas principais de efeitos. Primeiro, acarreta afetação ao patrimônio histórico, artístico e natural do bem em tela, com a consequente declaração sobre ele de conjunto de ônus de interesse público, sem que, como regra, implique desapropriação, de maneira a assegurar sua conservação para a posteridade. Segundo, institui obrigações concretas - de fazer, de não fazer e de suportar - incidentes sobre o proprietário, mas também sobre o próprio Estado. Terceiro, abre para a Administração Pública e para a coletividade, depositárias e guardiãs em nome das gerações futuras, a possibilidade de exigirem, em juízo, cumprimento desses deveres negativos e positivos, inclusive a restauração do bem ao status quo ante, sob regime de responsabilidade civil objetiva e solidária, sem prejuízo de indenização por danos causados, até mesmo morais coletivos.

O recorrente argumenta que notificou o Poder Público sobre a não possibilidade financeira para a realização de obras de conservação e preservação dos imóveis. Nesse ponto de análise, conclui o Relator que a falta de recursos não libera o proprietário do bem tombado para simplesmente "abandonar a coisa à própria sorte e ruína, sobretudo porque o ordenamento coloca à sua disposição mecanismos gratuitos para forçar a ação do Estado, bastando provocar o Ministério Público ou Defensoria Pública”. Diante isso, o Ministro decide pelo improvimento do recurso vez que entende que a demanda foi corretamente apreciada pelo Tribunal de origem ao decidir pela responsabilidade solidária.

Nota-se que, por meio do tombamento, a Corte está garantindo às futuras gerações o seu direito ao patrimônio histórico-cultural da mesma forma como as gerações presentes o receberam. Desse modo, fazem jus igualmente as futuras gerações à preservação da história bem como seus monumentos e manifestações culturais.

Os Ministros, em razão do princípio da indisponibilidade do bem público, caracterizam como ato de improbidade administrativa qualquer forma de Administração que, tanto por ação quanto por leniência dos servidores públicos, resultem na falta de zelo pela integridade e longevidade do patrimônio nacional.

Nas palavras do Ministro Herman Benjamin, em seu voto:

${ }^{21}$ BRASIL. Superior Tribunal de Justiça. REsp 1.359.534/MA, Relator: Min. Herman Benjamin, Segunda Turma, julgado em 20/02/2014, DJ-e 24/10/2016. 
A ocupação, a exploração e o uso de bem público, sobretudo os de interesse ambientalcultural e, com maior razão, aqueles tombados, só se admitem se contarem com expresso, inequívoco, válido e atual assentimento do Poder Público, exigência inafastável tanto pelo Administrador como pelo Juiz, a qual se mantém incólume, independentemente da ancianidade, finalidade (residencial, comercial ou agrícola) ou grau de interferência nos atributos que justificam sua proteção. ${ }^{22}$

Assim, o patrimônio cultural, histórico e natural, nestas três decisões, está sendo preservado eis que na primeira decisão negou-se provimento ao recurso e consequentemente acolheu-se os requerimentos do Município de Olinda em Ação Demolitória que pretendia a demolição de obra feita pela recorrente em imóvel tombado, em desconformidade com as previsões legais. Na segunda decisão, ao negar provimento ao recurso, não acolheu-se o pleito da recorrente, o qual aduzia direito à indenização por benfeitorias em imóvel público tombado, ilegalmente ocupado. E na terceira decisão houve preservação, na medida em que o Recurso Especial foi provido e reconheceu a violação, por parte do Distrito Federal, do Decreto-Lei n 25, de 30 de novembro de 1937 (que protege o patrimônio histórico e artístico nacional) ao permitir o gradeamento dos pilotis em bens que integram o projeto-piloto de Brasília, tombado em 1990.

Percebe-se que essas decisões visam garantir às gerações futuras uma vida sem imposições passadas, dificultando que a presente geração interfira no patrimônio, escolhendo qual merece ou não ser preservado.

\subsection{2 Áreas de preservação permanente e reserva legal}

Este subcapítulo tem como delimitação de tema decisões que envolvam demarcação, averbação, fiscalização e recomposição de reserva legal e áreas de preservação permanente.

Para que haja equilíbrio ambiental essas reservas naturais precisam ser preservadas. E, diferente do senso comum, a Área de Preservação Permanente e as Reservas Legais se distinguem no tocante à utilização de áreas naturais e ecológicas. Recebe o nome de Área de Preservação Permanente (APP) "área protegida, coberta ou não por vegetação nativa", que possibilite "preservar os recursos hídricos, a paisagem, a estabilidade geológica e a biodiversidade, facilitar o fluxo gênico de fauna e flora, proteger o solo e assegurar o bem-estar das populações humanas" (art. $3^{\circ}$, II, da Lei 12.651/2012). Já a Reserva Legal é a "área localizada no interior de uma propriedade ou posse rural", cuja preservação venha a "assegurar o uso econômico de modo sustentável dos recursos naturais do imóvel rural, auxiliar a conservação e a reabilitação dos processos ecológicos e promover a conservação da biodiversidade, bem como o abrigo e a proteção de fauna silvestre e da flora nativa" (art. $3^{\circ}$, III, da Lei 12.651/2012).

Passemos a analisar de que forma o Superior Tribunal de Justiça está atuando para garantir que as ameaças ao meio ambiente não se tornem hábitos que geram indiferença aos direitos das gerações vindouras, ou seja, para que não haja o exercício de uma sustentabilidade equivocada.

O Recurso Especial ${ }^{\circ}$ 1.362.456/MS ${ }^{23}$ de relatoria do Ministro Mauro Campbell Marques, tem por recorrente Ministério Público do Estado de Mato Grosso do Sul e por recorrido Darci Vieira de Barros. Cuida-se na origem de ação civil pública ambiental cuja hipótese é a ilegalidade

\footnotetext{
${ }^{22}$ BRASIL. Superior Tribunal de Justiça. REsp 808708/RJ, Relator: Min. Herman Benjamin, Segunda Turma, julgado em 18/08/2009, DJ-e 04/05/2011.

${ }^{23}$ BRASIL. Superior Tribunal de Justiça. REsp 1362456/MS, Relator: Min. Mauro Campell Marques, Segunda Turma, julgado em 20/06/2013, DJ-e 28/06/2013.
} 
da supressão da área de preservação permanente em face da construção de imóvel na margem do Rio IvinhemaMS. Nos autos demonstra-se a ausência de previsão legal autorizativa que legitime a conduta da recorrida.

Nas palavras do Ministro Relator:

Isso porque, sendo a licença espécie de ato administrativo autorizativo submetido ao regime jurídico administrativo, a sua nulidade implica que dela não pode advir efeitos válidos e tampouco a consolidação de qualquer direito adquirido (desde que não ultrapassado o prazo previsto no art. 54 da Lei ${ }^{\circ}$ 9784/99 caso o beneficiário esteja de boa fé). Vale dizer, declarada a sua nulidade, a situação fática deve retornar ao estado ex ante, sem prejuízo de eventual reparação civil do lesado, caso presentes os pressupostos necessários para tal. Essa circunstância se torna ainda mais acentuada tendo em vista o bem jurídico tutelado no caso em tela, que é o meio ambiente, e a obrigação assumida pelo Estado brasileiro em diversos compromissos internacionais de garantir o uso sustentável dos recursos naturais em favor das presentes e futuras gerações.

Por fim, o Relator reconheceu a existência de conduta nociva ao meio ambiente decorrente da ocupação e supressão de área de preservação permanente à margem do Rio Ivinhema/MT e, por conseguinte, determinou a remessa ao Ministério Público do Estado do Mato Grosso do Sul para apuração de prática de ato de improbidade administrativa ambiental. O Recurso especial foi provido por unanimidade.

O Recurso Especial n $n^{0} 1.222 .723 / \mathrm{SC}^{24}$, também de relatoria do Ministro Mauro Campbell Marques, tem por recorrente Dorival Gonzaga da Silva e outros e por recorrido Ministério Público Federal. Cuida-se de construção de condomínio no Município de Bombinhas, Santa Catarina. Alega o recorrente que a obra é tida como irregular pois além de ter sido edificada em área de preservação permanente (terreno de marinha), dela decorre inúmeros danos ao meio ambiente. O laudo do IBAMA/SC considerou a área do empreendimento como área de preservação permanente. E o parecer da perita nomeada no caso informa que seriam necessárias medidas para a recuperação da área que envolveriam "demolir o empreendimento, retirar a vegetação exótica e replantar vegetação nativa de encosta, típica desta região. Se a obra não for demolida, existe uma área significativa nos entornos da mesma que pode e deve ser recuperada."

O Relator, expressa em seu voto que "não há exagero no comando sentencial que determina a demolição da obra e a recuperação da área, posto que construída em área de preservação permanente e sem a observância das exigências legais." E cita o parecer do Ministério Público Federal, segundo o qual:

[...] constata-se que o empreendimento está situado em área de preservação permanente (dunas), na qual se encontra a presença da formação vegetal denominada restinga. [...] O objetivo principal é garantir às gerações futuras a possibilidade de sobrevivência em um espaço saudável, onde ainda se encontrem condições naturais que propiciem uma convivência harmônica.

O Recurso Especial foi conhecido parcialmente e, nessa parte, por unanimidade, negou-se provimento.

O Recurso Especial $n^{0}$ 1.179.316/SP ${ }^{25}$ teve a relatoria do Ministro Teori Albino Zavascki,

\footnotetext{
${ }^{24}$ BRASIL. Superior Tribunal de Justiça. REsp 1222723/SC, Relator: Min. Mauro Campbell Marques, Segunda Turma, julgado em 08/11/2011, DJ-e 17/11/2011.

${ }^{25}$ BRASIL. Superior Tribunal de Justiça. REsp 1179316/SP, Relator: Min. Teori Albino Zavascki, Primeira Turma, julgado em 15/06/2010, DJ-e 29/06/2010.
} 
sendo recorrente a Usina Santo Antônio S. A. e recorrido o Ministério Público do Estado de São Paulo. A lide versa sobre a violação às normas a respeito da demarcação, averbação e recomposição da reserva legal de vegetação nativa em propriedades rurais. $\mathrm{O}$ recorrente alega que adquiriu o imóvel com desmatamento feito por antecessores. Quanto a isso o relator do acórdão recorrido, Desembargador Samuel Júnior, define:

[...] ao adquirir o imóvel, o apelante assumiu o ônus legal de fazer o que seus antecessores deixaram de fazer e de refazer o que eles eventualmente tenham feito de forma ilegal, sendo, por isso, irrelevante que ele tenha recebido o imóvel desmatado. [...] a obrigação de possuir uma reserva legal na propriedade transfere-se do alienante ao adquirente, independentemente de este último ter responsabilidade acerca da degradação da referida reserva. [...] a ocupação integral do imóvel, impedindo a regeneração, numa área de pelo menos $20 \%$, da mata originária, implica evidentemente em transgressão à Política Nacional do Meio Ambiente, tratada na Lei Ordinária nº 6.93881.

Para o Relator, o entendimento da segunda instância guarda perfeita harmonia com a jurisprudência do STJ sobre a matéria e, com base no Código Florestal anterior (art. 16, da Lei 4.771/65), defende "que a obrigação de demarcar, averbar e restaurar a área de reserva legal nas propriedades rurais constitui limitação administrativa ao uso da propriedade privada destinada a tutelar o meio ambiente, que deve ser defendido e preservado "para as presentes e futuras gerações"”, conforme previsão constitucional (CF, art. 225).

Concorda também com o voto do Desembargador Relator do acórdão recorrido no sentido de que "[...] o percentual legal de reserva florestal tem por base a totalidade da área, e não a parcela da área onde ainda exista vegetação, como defende o recurso. Assim, a área a ser considerada [...] não é a área "florestada", como quer a recorrente, mas sim a área "florestável"." Quanto a limitação do uso da propriedade e as prestações dela decorrentes, afirma o Relator que não aplica-se a hipótese de retroatividade da norma ambiental eis que assim violaria o art. $6^{\circ}$ da Lei de Introdução ao Código Civil. Porém, sua aplicação é imediata, sendo desde logo exigíveis as prestações dela decorrentes. Quanto à reserva legal, o recorrido alega a não demarcação e averbação da reserva legal e o autor comprovou que não há averbação de reserva legal à margem da inscrição da matrícula da propriedade. Desse modo, conheceu-se parcialmente do Recurso Especial e nessa parte, por unanimidade, nagaram-lhe o provimento.

O Recurso Especial $n^{\circ} 1.087 .370 / \mathrm{PR}^{26}$ de relatoria da Ministra Denise Arruda, tem por recorrentes Instituto Brasileiro do Meio Ambiente e dos Recursos Naturais Renováveis (IBAMA) e Estado do Paraná e por recorrido Ministério Público Federal. Cuida-se, na origem, de Ação Civil Pública que, parcialmente procedente, condenou o IBAMA e o Estado do Paraná a delimitar a área total de reserva legal e a área de preservação permanente da propriedade, no prazo de sessenta dias, sob pena de multa a ser rateada entre ambos e fiscalizar, a cada seis meses, a realização das medidas imputadas ao proprietário do imóvel: (a) preservar área de vinte por cento da superfície da sua propriedade, a título de reserva legal, e efetuar a reposição florestal gradual; (b) preservar também as matas ciliares (preservação permanente) na faixa de trinta metros às margens dos rios e cinquenta metros nas nascentes e nos chamados "olhos d'água"; sob pena de multa diária. O IBAMA alega em seu recurso que a responsabilidade pela delimitação da área de reserva legal é do proprietário rural, incumbindo ao órgão ambiental somente a aprovação da sua localização.

Nas palavras da Ministra:

\footnotetext{
${ }^{26}$ BRASIL. Superior Tribunal de Justiça. REsp 1087370/PR, Relatora: Min. Denise Arruda, Primeira Turma, julgado em 10/11/2009, DJ-e 27/11/2009.
} 
A delimitação e a averbação da reserva legal constitui responsabilidade do proprietário ou possuidor de imóveis rurais, que deve, inclusive, tomar as providências necessárias à restauração ou à recuperação das formas de vegetação nativa para se adequar aos limites percentuais previstos nos incisos do art. 16 do Código Florestal.

Diante isso, a Relatora entendeu ser incumbência do proprietário do imóvel a delimitação da área de reserva legal e a área de preservação permanente. Porém não prosperou o recorrente quanto ao seu poder-dever de fiscalização com base no art. 22 do mesmo Código e com base também na Lei $7.735 / 89$, art. $2^{\circ}$.

No voto, a Ministra considerou a competência comum dos três entes federativos para a proteção do meio ambiente (art. 23, VI, CF) reforçando o alcance dessa proteção para as presentes e futuras gerações (art. 225, CF). O Recurso Especial foi, por unanimidade, parcialmente provido.

O Recurso Ordinário em Mandado de Segurança $\mathrm{n}^{\mathbf{2}} 22.391 / \mathrm{MG}^{27}$ teve a relatoria da Ministra Denise Arruda, sendo recorrente o Ministério Público do Estado de Minas Gerais e recorrido o Estado de Minas Gerais. Cuida-se, na origem, de Ação Mandamental na qual o Tribunal de origem entendeu que a averbação da área de reserva legal, nos atos de transmissão de imóveis rurais realizados perante o Ofício de Registro de Imóveis da Comarca de São Sebastião do Paraíso MG, somente seria obrigatória em relação às áreas onde houvesse florestas, campos gerais ou outra forma de vegetação nativa.

Em seu voto, a Ministra, com base no art. 16 do Código Florestal anterior, defende "que a exigência de averbação da reserva legal à margem da inscrição de matrícula do imóvel, no ofício de registro de imóveis competente, não se aplica somente às áreas onde haja florestas, campos gerais ou outra forma de vegetação nativa." Diante isso, determinou que fosse cumprida a norma prevista no $\S 8^{\circ}$ do art. 16 do antigo Código Florestal, a qual determinava a averbação da área de reserva legal. $\mathrm{O}$ Recurso foi provido por unanimidade.

O Recurso Especial n ${ }^{\circ}$ 948.921/SP ${ }^{28}$, de relatoria do Ministro Herman Benjamin, tem por recorrente Companhia Açucareira São Geraldo e por recorrido Ministério Público do Estado de São Paulo. Alega a Recorrente que adquiriu o imóvel já desmatado em 1983, ou seja, mais de 6 anos antes da existência da norma instituidora da reserva legal, o qual já não possuía a cobertura florestal e assim já estava quando foi adquirido. Ademais, não derrubou nenhuma floresta nativa, fosse primitiva ou sequer regenerada. Assim, eventual desmatamento teria ocorrido em épocas longínquas, por algum dos proprietários anteriores, e o imóvel tem sido utilizado há décadas em sua integralidade para cultivo de cana-de-açúcar. Alega que o dispositivo que criou tal "área" de reserva legal somente foi introduzido na Lei $\mathrm{n}^{\circ} 4.771 / 1965$ em 1989, por meio da Lei ${ }^{\circ} 7.803 / 89$, que alterou a primeira, criando novos dispositivos e lhe dando nova redação. Alega violação ao ato jurídico perfeito e ao direito adquirido ao se admitir a retroatividade da norma jurídica.

Quanto à tese da empresa, o Relator entendeu ser inadmissível pretender utilizar a norma de 1989 para defender a tese de que antes disso inexistia a proibição legal de desmatamento e a vedação de utilização integral do imóvel pois a inovação que trouxe a Lei $n^{\circ} 7.803 / 89$ não foi quanto à instituição da obrigação de conservar a Reserva Legal, mas simplesmente de averbá-la no registro imobiliário. Também não se sustentou o argumento da empresa de que as normas instituidoras da Reserva Legal só se apliquem aos detentores de áreas ainda com florestas nativas

\footnotetext{
${ }^{27}$ BRASIL. Superior Tribunal de Justiça. RMS 22391/MG, Relatora: Min. Denise Arruda, Primeira Turma, julgado em 04/11/2008, DJ-e 03/12/2008.

${ }^{28}$ BRASIL. Superior Tribunal de Justiça. REsp 948921/SP, Relator: Min. Herman Benjamin, Primeira Turma, julgado em 23/10/2007, DJ-e 11/11/2009.
} 
porque "a ser como quer a empresa, bastaria desmatar ilegalmente, para desaparecer o dever de manter a Reserva Legal. Um prêmio e incentivo aos que desejavam pôr abaixo suas Matas". E ainda, "[...] quem adquire imóvel desmatado ilegalmente, ou com irregularidades perante a legislação de proteção do meio ambiente recebe-o como também com os ônus ambientais que sobre ele incidam."

Nas palavras do Ministro Relator:

Inexiste direito adquirido a poluir ou degradar o meio ambiente. O tempo é incapaz de curar ilegalidades ambientais de natureza permanente, pois parte dos sujeitos tutelados as gerações futuras - carece de voz e de representantes que falem ou se omitam em seu nome.

Décadas de uso ilícito da propriedade rural não dão salvo-conduto ao proprietário ou posseiro para a continuidade de atos proibidos ou tornam legais práticas vedadas pelo legislador, sobretudo no âmbito de direitos indisponíveis, que a todos aproveita, inclusive às gerações futuras, como é o caso da proteção do meio ambiente.

As APPs e a Reserva Legal justificam-se onde há vegetação nativa remanescente, mas com maior razão onde, em conseqüência de desmatamento ilegal, a flora local já não existe, embora devesse existir.

Diante isso, conheceu-se parcialmente do Recurso Especial e nessa parte, por unanimidade, nagaram-lhe o provimento.

O Recurso Ordinário em Mandado de Segurança ${ }^{\circ} 18.301 / \mathrm{MG}^{29}$ de relatoria do Ministro João Otávio de Noronha, tem por recorrente o Ministério Público do Estado de Minas Gerais e por recorrido o Estado de Minas Gerais. Cuida-se, na origem, de Ação Mandamental contra ato normativo do Juiz de Direito da Comarca de Andrelândia, Minas Gerais, visando a decretação da nulidade da Portaria $n^{\circ} 001 / 2003$, que permitia a transcrição de títulos aquisitivos de imóveis sem a respectiva averbação da reserva legal instituída pelo Código Florestal anterior. Esse pleito foi denegado pelo Tribunal de Justiça do Estado de Minas Gerais.

O Ministro, com base no Código Florestal anterior, fundamenta:

Essa legislação, ao determinar a separação de parte das propriedades rurais para constituição da reserva florestal legal, resultou de uma feliz e necessária consciência ecológica que vem tomando corpo na sociedade em razão dos efeitos dos desastres naturais ocorridos ao longo do tempo, resultado da degradação do meio ambiente efetuada sem limites pelo homem. Tais conseqüências nefastas, paulatinamente, leva à conscientização de que os recursos naturais devem ser utilizados com equilíbrio e preservados em intenção da boa qualidade de vida das gerações vindouras. O que se tem presente é o interesse público prevalecendo sobre o privado, interesse coletivo este que inclusive afeta o proprietário da terra reservada, no sentido de que também será beneficiado com um meio ambiente estável e equilibrado. Assim, a reserva legal compõe parte de terras de domínio privado e constitui verdadeira restrição do direito de propriedade.

Desse modo, o Relator entendeu que a portaria desconsiderou o bem jurídico por ela protegido. No entanto, determinou que sua decisão sofreria apenas efeitos ex nunc haja vista que o número de transcrições de títulos aquisitivos efetivados sob a égide da mencionada portaria era indeterminado. Além disso, não se estava diante de ação coletiva com efeitos erga omnes e o Código Florestal anterior não dispôs expressamente sobre o prazo de averbação. O Recurso

${ }^{29}$ BRASIL. Superior Tribunal de Justiça. RMS 18301/MG, Relator: Min. João Otávio de Noronha, Segunda Turma, julgado em 24/08/2005, DJ 03/10/2005, p. 157. 
Ordinário em Mandado de Segurança foi provido por unanimidade.

O Recurso Especial n ${ }^{\circ}$ 1.221.867/ $\mathrm{MG}^{30}$ de relatoria do Ministro Herman Benjamin, tem por recorrente Janette Jader Barbosa e por recorrido Ministério Público do Estado de Minas Gerais. Trata-se o feito de obrigação de averbação de área de reserva legal à margem da inscrição de matrícula de imóvel. Alega a recorrente que não cabe ao registrador recusar a averbação ou o registro de outros atos à margem da matrícula pela inexistência de averbação da reserva legal.

Em seus votos, afirma o Relator, que a jurisprudência do Tribunal Superior é "pacífica no sentido de reconhecer a natureza propter rem das obrigações ambientais, nelas incluída a reserva legal, donde decorre o caráter vinculante e indeclinável para o proprietário atual e o Poder Público". Cita, ainda, o Relator, voto ${ }^{31}$ do Ministro Teori Zavascki sobre o tema:

Em nosso sistema normativo (Código Florestal - Lei 4.771/65, art. 16 e parágrafos; Lei 8.171/91, art. 99), a obrigação de demarcar, averbar e restaurar a área de reserva legal nas propriedades rurais constitui (a) limitação administrativa ao uso da propriedade privada destinada a tutelar o meio ambiente, que deve ser defendido e preservado 'para as presentes e futuras gerações' (CF, art. 225). Por ter como fonte a própria lei e por incidir sobre as propriedades em si, (b) configura dever jurídico (obrigação ex lege) que se transfere automaticamente com a transferência do domínio (obrigação propter rem), podendo, em consequência, ser imediatamente exigível do proprietário atual, independentemente de qualquer indagação a respeito de boa-fé do adquirente ou de outro nexo causal que não o que se estabelece pela titularidade do domínio.

O Relator entende que não se pode esperar do delegatário registrador uma postura passiva que o separe dos outros sujeitos estatais e o imunize contra a força vinculante dos mandamentos constitucionais e legais. À vista disso, negou-se provimento ao Recurso Especial.

O Recurso Especial n ${ }^{\mathrm{o}}$ 1.357.263/PR ${ }^{32}$ de relatoria do Ministro Herman Benjamin, tem por recorrente Luiz Guilherme Possan, por recorrido o IBAMA e o Ministério Público Federal. O acórdão recorrido sustenta que a atividade econômica, mesmo objetivando auferir o sustento familiar, tem como pressuposto a defesa ecológica e, sendo assim, o direito de propriedade não abarca atividades que não se coadunam com o interesse coletivo ao meio ambiente. Determina, também, a aplicação de multa em face de ilícito ambiental praticado pelo proprietário particular ao desmatar áreas de preservação permanente sem autorização, com a seguinte validação.

A recorrente, por sua vez, alega que sofreu em sua propriedade desapropriação indireta e não limitação ao direito de uso, pleiteando a devida indenização. No caso em tela, discorre o Relator que a recorrente não foi desapossada de sua propriedade, senão apenas lhe foi limitada a utilização econômica em razão da proteção ambiental. No mérito, o Relator cita julgados de sobre o assunto, dos quais destaca-se: "Em se tratando de reserva florestal, com limitação imposta por lei, o novo proprietário, ao adquirir a área, assume o ônus de manter a preservação, tornando-se responsável pela reposição, mesmo que não tenha contribuído para devastá-la" ${ }^{33}$.

Ainda nesse tocante, sustenta o Relator que a instituição da reserva legal ou de áreas de preservação permanente decorre diretamente da função ecológica da propriedade e, ao discipliná-

\footnotetext{
${ }^{30}$ BRASIL. Superior Tribunal de Justiça. REsp 1.221.867/MG, Relator: Min. Herman Benjamin, Segunda Turma, julgado em 15/05/2012, DJ-e 24/10/2016.

${ }^{31}$ BRASIL. Superior Tribunal de Justiça. REsp 1.179.316/SP, Relator: Min. Teori Albino Zavascki, Primeira Turma, DJ-e 29/06/2010.

${ }^{32}$ BRASIL. Superior Tribunal de Justiça. REsp 1.357.263/PR, Relator: Min. Herman Benjamin, Segunda Turma, julgado em 16/05/2013, DJ-e 17/11/2016.

33 BRASIL. Superior Tribunal de Justiça. REsp 282.781/PR, Relatora: Min. Eliana Calmon, Segunda Turma, DJ-e $27 / 05 / 2002$.
} 
las, o legislador e o administrador "nada retiram do dono do imóvel, na medida em que, à luz da Constituição de 1988, a ninguém se faculta arrogar-se senhor absoluto dos bens ambientais, com menor razão ainda de recursos planetários".

Quanto à indenização pretendida pela recorrente, pronuncia-se o Relator no sentido de ser uma pretensão irracional eis que a obrigação legal é exigida de todos. A pretensão da recorrente demonstra a busca por um duplo benefício, que seria o lucro da atividade econômica adicionado a pagamento para reparar danos causados, enquanto a sociedade suportaria, ao mesmo passo, o padecimento da lei, os impactos materiais e morais da infração e o dispêndio de recursos estatais escassos para "comprar bom comportamento de quem se rebela contra sábias prescrições do legislador".

Sendo assim, o Relator traduz a pretensão da recorrida:

Traduzida em miúdo, essa expectativa, tão despropositada como infelizmente comum, realça ao extremo a perversa e antirrepublicana prática de apropriação privada dos benefícios dos recursos ambientais e a socialização, com a coletividade e as gerações futuras, dos ônus, custos e externalidades negativas da exploração predatória, empobrecimento e contaminação da Natureza.

Assim, o Relator negou provimento ao Recurso Especial.

O Recurso Especial $\mathrm{n}^{\mathrm{o}}$ 1.381.191/ $\mathrm{SP}^{34}$ de relatoria da Ministra Diva Malerbi (Desembargadora convidada TRF $3^{\mathrm{a}}$ região), tem por recorrente a Agropecuária Iracema LTDA. e por recorrido o Ministério Público do Estado de São Paulo. Alega a recorrente, invocando o ato jurídico perfeito, o direito adquirido e os princípios da irretroatividade da lei, a impossibilidade de obrigá-la a realizar reflorestamento de gleba rural tendo em vista a vigência do Código Florestal, a categoria de vegetação a ser preservada e a consolidação de fatos na vigência de lei anterior. Defende que o percentual da reserva legal deve incidir sobre as matas existentes ao tempo da edição da lei e não sobre a extensão total da propriedade.

No tocante ao aspecto do direito adquirido exposto pela recorrente, afirma a Relatora:

No tocante à ofensa ao art. $6^{\circ}$ da LINDB, deve-se registrar que o direito adquirido não pode ser invocado para mitigar a salvaguarda ambiental, não servindo para justificar o desmatamento da flora nativa, a ocupação de espaços especialmente protegidos pela legislação, tampouco para autorizar a continuidade de conduta potencialmente lesiva ao meio ambiente. $\mathrm{O}$ dever de assegurar o meio ambiente não se limita à proibição da atividade degradatória, abrangendo a obrigatoriedade de se conservar e regenerar os processos ecológicos.

Sustenta a Relatora que não se cogita no caso a aplicação retroativa da lei, "pois a obrigação de instituir a área de reserva legal, bem como de recompor a cobertura florestal e as áreas de preservação permanente foi estabelecida após a vigência dos normativos de regência". Defende que a limitação administrativa é necessária à tutela do meio ambiente para as presentes e futuras gerações e coaduna-se com a função ecológica da propriedade.

Quanto à categoria de vegetação ou sua existência na gleba, entende que independe sua existência ou característica para a averbação da reserva legal. Sendo obrigação do adquirente recuperar e restaurar essas áreas, a fim de readequar-se aos limites percentuais previstos na lei de regência. Sendo assim, negou-se provimento ao recurso.

\footnotetext{
${ }^{34}$ BRASIL. Superior Tribunal de Justiça. REsp 1.381.191/SP, Relatora: Min. Diva Malerbi, Segunda Turma, julgado em 16/06/2016, DJ-e 30/06/2016.
} 
Por fim, no Recurso Especial n ${ }^{0}$ 1.276.114/ $\mathrm{MG}^{35}$ a relatoria foi do Ministro Og Fernandes, sendo recorrente Minerações Brasileiras Reunidas S. A. e recorrido o Ministério Público do Estado de Minhas Gerais. Trata-se de recurso interposto a fim de que se reconheça a inexigibilidade da averbação da área de reserva legal como condição para o registro da escritura imobiliária da propriedade rural. De acordo com a recorrente, a exigibilidade impossibilita a demonstração de que não há área de floresta ou vegetação nativa na propriedade objeto da aquisição e, além disso, que a limitação administrativa deve ser exigida apenas a quem pretende suprimir floresta ou vegetação nativa existente ou sua exploração.

O Relator entende que somente há dispensa de averbação de reserva legal no cartório de imóveis nos casos em que ela já esteja registrada no Cadastro Ambiental Rural (CAR). Traz o entendimento pacífico do STJ de que a obrigação de demarcar, averbar e restaurar área de reserva legal é um dever propter rem, ou seja, se transfere automaticamente ao adquirente ou possuidor do imóvel. Além disso, a limitação é necessária à tutela do meio ambiente para as presentes e futuras gerações e está em harmonia com a função social da propriedade.

O Relator cita casos análogos julgados pelas Terceira e Quarta Turmas, que concluem pela averbação da reserva legal como condição para realizar qualquer ato relativo à transmissão, ao desmembramento ou à retificação de área de imóvel rural ${ }^{36}$. Assim sendo, nega provimento ao Recurso Especial.

Assim, analisando-se as decisões, percebe-se que as áreas de prevenção permanente e reserva legal estão sendo preservadas. A primeira decisão reconheceu a supressão de área de preservação permanente à margem do Rio Ivinhema/MT, determinando que a situação retornasse ao estado ex ante. Na segunda decisão, determinou-se também que a situação retornasse ao estado ex ante por situar-se em área de preservação permanente. Já na terceira e na sexta decisão, ao negarse provimento, decidiu-se que o novo proprietário assume os ônus ambientais que sobre o imóvel incidam e, também, que o percentual legal de reserva florestal tem por base a totalidade da área e não a parcela da área onde ainda exista vegetação para fins de averbação, tendo sido reconhecido este último na quinta e na sétima decisão. Na quarta decisão, ao prover parcialmente o recurso, entendeu-se que o IBAMA é o órgão responsável pela fiscalização da área de reserva legal e da área de preservação permanente, porém é dever do proprietário sua delimitação.

A partir dessas decisões denota-se a preocupação da Corte em seguir fielmente a Lei Florestal vigente e, assim, garantir às futuras gerações a equidade no acesso à biodiversidade, à fauna e à flora, aos recursos hídricos e outros bens ambientais, bem como a exploração de áreas de forma sustentável provendo a regeneração da natureza. Percebe-se também que as ameaças à natureza tornam-se hábitos. É espantoso alguns cidadãos, nos dias de hoje, questionarem a importância dessas áreas, mesmo que haja normas protetoras do meio ambiente há pelo menos 40 anos, inicialmente com a Lei 4.771/65 e atualmente com a Lei 12.651/2012.

\subsubsection{Responsabilidade civil por danos ambientais}

Este subcapítulo tem como delimitação de tema decisões que demonstrem o entendimento da Corte Superior a cerca da obtenção de indenização por danos ao meio ambiente e sua imprescritibilidade verificando se desse entendimento resulta a proteção das futuras gerações

\footnotetext{
${ }^{35}$ BRASIL. Superior Tribunal de Justiça. REsp 1.276.114/MG, Relator: Min. Og Fernandes, Segunda Turma, julgado em 04/10/2016, DJ-e 11/10/2016.

${ }^{36}$ BRASIL. Superior Tribunal de Justiça. REsp 831.212/MG, Relatora: Min. Nancy Andrighi, Terceira Turma, julgado em 01/09/2009, DJ-e 22/09/2009.
} 
contra os degradadores.

\section{a) Imprescritibilidade do dano ambiental}

A prescrição se refere à perda da ação, ou seja, "é a perda da ação atribuída a um direito, e de toda a sua capacidade defensiva, em consequência do não-uso delas, durante um determinado espaço de tempo." 37 Por ser o meio ambiente de ordem pública não há que se falar em prescrição à pretensão de indenização do dano ambiental considerando, ainda, seu caráter essencial conforme dispõe o art. 225, da Constituição Federal. Essa é a diretriz das decisões a seguir analisadas.

O Agravo Regimental no Recurso Especial $n^{0} 1.150 .479 / \mathrm{RS}^{38}$, de relatoria do Ministro Humberto Martins, tem por agravante a Petrobrás Gás S. A. (GASPETRO) e agravados o Ministério Público Federal, o Instituto Brasileiro do Meio Ambiente e dos Recursos Naturais Renováveis (IBAMA), o Município de Criciúma e o Município de Forquilhinha. Requer a agravante o reconhecimento de prazo prescricional para ações civis públicas em matéria ambiental e alega que a imprescritibilidade é a exceção, carecedora de previsão legal no ordenamento jurídico pátrio. O Tribunal a quo entendeu que:

O julgado invocado pelo demandado, onde foi aplicada a prescrição, trata-se de ação civil pública que busca o "ressarcimento de danos ao patrimônio público". Não se pode aplicar entendimento adotado em ação de direitos patrimoniais em ação que visa à proteção do meio ambiente, cujos efeitos danosos se perpetuam no tempo, atingindo às gerações presentes e futuras.

O Relator, em seu voto, teve um entendimento no mesmo sentido: "tratando-se de direito difuso, - proteção ao meio ambiente -, a ação de reparação é imprescritível'. E, dessa forma, negouse provimento, por unanimidade, ao Agravo Regimental.

O Recurso Especial n $\mathrm{n}^{\mathrm{O}} 1.120 .117 / \mathrm{AC}^{39}$ teve a relatoria da Ministra Eliana Calmon, sendo recorrente Orleir Messias Cameli e outros e recorridos Ministério Público Federal e Fundação Nacional do Índio (FUNAI). Cuida-se na origem de Ação Civil Pública tendo em vista danos materiais e morais decorrentes da extração ilegal de madeira da área indígena por parte dos recorrentes. $\mathrm{O}$ recorrente requer seja afastada a prescrição vintenária para obtenção de indenização por danos ao meio ambiente decorrente de invasão a terra indígena baseada no Código Civil de 1916 e tendo em vista o silêncio quanto ao prazo na Lei da Ação Civil Pública requer seja aplicada a prescrição quinquenal da Lei da Ação Popular.

Ao iniciar seu voto quanto ao tema, a Relatora cita a lição do Ministro Herman Benjamin sobre a conceituação do direito ao meio ambiente:

Antes de mais nada, o bem jurídico tutelado integra a categoria daqueles valores fundamentais da nossa sociedade. Com a proteção do meio ambiente salvaguardamos não só a vida nas suas várias dimensões (individual, coletiva e até das gerações futuras), mas as próprias bases da vida, o suporte planetário que viabiliza a existência da integralidade dos seres vivos. (in Responsabilidade Civil pelo Dano Ambiental, Revista de Direito Ambiental, São Paulo, v. 9, ano 3, p. 17-18, jan/mar. 1998).

\footnotetext{
${ }^{37}$ BEVILACQUA, Clóvis. Teoria Geral do Direito Civil. Ed. Servanda. São Paulo, 2007, p. 175.

${ }^{38}$ BRASIL. Superior Tribunal de Justiça. AgRg no REsp 1150479/RS, Relator: Min. Humberto Martins, Segunda Turma, julgado em 04/10/2011, DJ-e 14/10/2011.

${ }^{39}$ BRASIL. Superior Tribunal de Justiça. REsp 1120117/AC, Relatora: Min. Eliana Calmon, Segunda Turma, julgado em 10/11/2009, DJ-e 19/11/2009.
} 
Cita também o voto do Ministro Celso de Mello:

\begin{abstract}
Direito ao meio ambiente é um típico direito de terceira geração que assiste, de modo subjetivamente indeterminado, a todo o gênero humano, circunstância essa que justifica a especial obrigação - que incube ao Estado e à própria coletividade - de defendê-lo e de preservá-lo em benefício das presentes e das futuras gerações, evitando-se, desse modo, que irrompam, no seio da comunhão social, os graves conflitos intergeracionais marcados pelo desrespeito ao dever de solidariedade na proteção da integridade desse bem essencial de uso comum de todos quantos compõem o grupo social. (MS 22164, Relator Min. Celso de Mello, Tribunal Pleno, julgado em 30.10.1995, DJ 17.11.1995).
\end{abstract}

Quanto à responsabilidade civil por dano ambiental entende a relatora que se consolidou no ordenamento jurídico a responsabilidade objetiva do degradador e, ainda cita o art. $225, \S 3^{\circ}$ da Constituição Federal.

Quanto ao tema central, a prescrição, a Relatora entende que o afastamento da prescrição deve apoiar-se em previsão legal, portanto aplica o art. $37, \S 5^{\circ}$ da Constituição Federal e destaca que o direito ao pedido de reparação de danos ambientais “"...] também está protegido pelo manto da imprescritibilidade, por se tratar de direito inerente à vida, fundamental e essencial a afirmação dos povos, independentemente de estar expresso ou não em texto legal”.

Por fim, decide a relatora em prol de beneficiar o bem jurídico coletivo eis que antecede os demais direitos, inclusive a segurança jurídica do degradador. O Recurso Especial foi parcialmente conhecido e, nessa parte, por unanimidade, negou-se provimento.

\title{
b) Responsabilidade civil por danos ambientais e cumulação de obrigações
}

Este tópico tem como delimitação de tema decisões que envolvam ressarcimento de danos causados por degradadores, predominantemente ações que nas quais se discute a cumulação das obrigações de fazer e pagar. A responsabilidade civil do poluidor, conforme a Lei da Política Nacional do Meio Ambiente, é objetiva, ou seja, independe de culpa para reparar ou indenizar os danos causados ao meio ambiente.

Conforme Paulo Affonso Leme Machado40 "a atividade poluente acaba sendo uma apropriação pelo poluidor dos direitos de outrem, pois na realidade a emissão poluente representa um confisco do direito de alguém em respirar ar puro, beber água saudável e viver com tranquilidade". Dessa forma, é necessário que se analisem as modalidades de reparação do dano ecológico aplicadas pelo STJ, considerando que ninguém está autorizado a praticar uma agressão que leve a perda de chance de vida das futuras gerações.

O Recurso Especial no 1.172.553/PR ${ }^{41}$, de relatoria do Ministro Arnaldo Esteves Lima, tem por recorrente Duke Energy International Geração Paranapanema S. A. e por recorrido Instituto Ambiental do Paraná (IAP). Cuida-se, na origem, de ação civil pública objetivando a recomposição de danos ambientais decorrentes da construção do reservatório da Usina Hidrelétrica de Chavantes, no Estado do Paraná. No primeiro grau, acolheu-se o pedido do IAP para que fosse providenciada a elaboração de Estudo de Impacto Ambiental - EIARIMA. Alega a recorrente desnecessidade de elaboração de EIARIMA para o empreendimento e a falta de interesse de agir por parte dos recorridos, já que os danos materiais por eles pleiteados já foram ressarcidos em cumprimento à

\footnotetext{
${ }^{40}$ MACHADO, Paulo Affonso Leme. Direito Ambiental Brasileiro. São Paulo: Editora Malheiros, 2014 , p. 403.

${ }^{41}$ BRASIL. Superior Tribunal de Justiça. REsp 1172553/PR, Relator: Min. Arnaldo Esteves Lima, Primeira Turma, julgado em 27/005/2014, DJ-e 04/06/2014.
} 


\title{
Lei 7.990/89.
}

$\mathrm{O}$ voto do Relator foi no sentido de que não se pode alegar a inexistência de interesse de agir em pleitear indenização pelo fato de a mesma já estar regulamentada na Lei No 7.990/89, tendo em vista que referido diploma normativo trata da "compensação financeira pela utilização dos recursos hídricos", não se confundindo, portanto, com o ressarcimento dos danos causados ao meio ambiente. O pagamento de 'royalties' se dá não pela degradação do meio ambiente, mas como forma de compensação pela utilização dos recursos hídricos do Município.

Nas palavras do Ministro Relator:

\begin{abstract}
A implantação de uma usina hidrelétrica inviabiliza o desenvolvimento de atividades produtivas na superfície, em decorrência da inundação de grande área, privando, assim, estados e municípios das vantagens econômicas dela decorrente. Diferentemente, a degradação do meio ambiente deve ser aferida e aquilatada a fim de que seja reparada a lesão, por meio patrimonial, perpetrada ao bem jurídico pertencente à coletividade.

Ademais, a natureza do direito ao meio ambiente ecologicamente equilibrado fundamental e difusa - não confere ao empreendedor direito adquirido de, por meio do desenvolvimento de sua atividade, agredir a natureza, ocasionando prejuízos de diversas ordens à presente e futura gerações. Entendimento contrário violaria comando normativo constitucionalmente estatuído.

$[\ldots]$

Inexiste direito adquirido a poluir ou degradar o meio ambiente. O tempo é incapaz de curar ilegalidades ambientais de natureza permanente, pois parte dos sujeitos tutelados as gerações futuras - carece de voz e de representantes que falem ou se omitam em seu nome.
\end{abstract}

Por fim, relativamente à exigência de elaboração do Estudo Prévio de Impacto Ambiental e do Relatório de Impacto Ambiental (EIARIMA), entendeu que não se pode deixar de exigir o cumprimento do dever legal e também a garantia do bem-estar futuro das próximas gerações. E, “já que anteriormente à implantação da Usina não foi exigido o estudo prévio, atrita com o senso lógico pretender a realização de prévio Estudo de Impacto Ambiental num empreendimento que está em atividade desde 1971, isto é, há 43 anos". Portanto, afastou a exigência de elaboração do EIA/RIMA. Entretanto, impôs a realização de perícia técnica para aquilatar os impactos físicos e econômicos decorrentes das atividades desenvolvidas pela Usina. O Recurso especial, por unanimidade, foi parcialmente provido.

O Recurso Especial n ${ }^{\circ} 1.269 .494 / \mathrm{MG}^{42}$ teve a relatoria da Ministra Eliana Calmon, sendo recorrente o Ministério Público do Estado de Minas Gerais e recorrida a Fundação Uberlandense de Turismo Esporte e Lazer (FUTEL). Cuida-se, na origem, de ação civil pública ambiental referente à impropriedade da água destinada ao consumo e balneabilidade para os usuários, ao manejo incorreto das formações vegetais e à situação irregular dos animais do zoológico. $\mathrm{O}$ Tribunal de origem reformou a sentença para eximir os recorridos da condenação de multa e negou provimento à apelação do recorrente quanto aos danos morais coletivos.

$\mathrm{O}$ voto da Relatora foi no sentido de que o acórdão recorrido, ao rejeitar a condenação cumulativa de cumprimento de obrigação de fazer ou não fazer e indenização em pecúnia, o fez de forma motivada, a partir da exegese que conferiu ao art. $3^{\circ}$ da Lei 7.347/85. O Tribunal interpretou que a conjunção "ou" exprimia alternatividade dos objetivos perseguidos pela ação civil pública, sendo vedada a cumulação da condenação. Ainda, baseou-se na Lei 6.938/81, que foi elaborada

\footnotetext{
${ }^{42}$ BRASIL. Superior Tribunal de Justiça. REsp 1269494/MG, Relatora: Min. Eliana Calmon, Segunda Turma, julgado em 24/09/2013, DJ-e 01/10/2013.
} 
com o intuito de assegurar, em primeiro plano, a reparação do meio ambiente degradado, para, somente quando não possível e de forma subsidiária, impor ao infrator indenização em pecúnia.

Porém, nas palavras da Ministra:

[...] deve o magistrado, ao aplicar as normas de Direito Ambiental, considerar o comando do art. $5^{\circ}$ da Lei de Introdução às normas do Direito Brasileiro, para 'atender aos fins sociais a que ela se dirige e às exigências do bem comum'. Derivado dessa regra é o caso em que, havendo dúvida ou alguma anomalia técnica, a norma ambiental deve ser interpretada ou integrada de acordo com o princípio hermenêtico in dubio pro natura. Portanto, a recuperação da área degradada não exime o degradador do meio ambiente da responsabilidade pelo pagamento de indenização.

Quanto à condenação dos recorridos por dano moral coletivo, a Relatora entendeu que a lesão aos interesses de massa não podem ficar sem reparação sob pena de criar-se litigiosidade contida que levará ao fracasso do direito como forma de prevenir e reparar os conflitos sociais.

Em suma, pode-se elencar como pressupostos necessários à configuração do dano moral coletivo, de maneira a ensejar a sua respectiva reparação, (1) a conduta antijurídica (ação ou omissão) do agente, pessoa física ou jurídica; (2) a ofensa a interesses jurídicos fundamentais, de natureza extrapatrimonial, titularizados por uma determinada coletividade (comunidade, grupo, categoria ou classe de pessoas); (3) a intolerabilidade da ilicitude, diante da realidade apreendida e da sua repercussão social; (4) o nexo causal observado entre a conduta e o dano correspondente à violação do interesse coletivo (lato sensu).

Como visto, a Relatora entendeu pela cumulação de indenização pecuniária com as obrigações de fazer direcionadas à recomposição do bem lesado, bem como a condenação em danos morais coletivos. Recurso Especial provido por unanimidade.

O Recurso Especial n ${ }^{\circ}$ 1198727/MG ${ }^{43}$, de relatoria do Ministro Herman Benjamin, tem por recorrente o Ministério Público do Estado de Minas Gerais e por Recorrido Pedro Paulo Pereira. Trata-se de Ação Civil Pública em razão de desmatamento de cerrado sem autorização do órgão competente. O Tribunal de origem entendeu que "a indenização é cabível (somente) quanto aos danos insuscetíveis de recomposição in natura, sendo que o aspecto repressor ficará a cargo da aplicação da penalidade cabível pela administração" e o Relator entendeu que essa decisão merece reforma.

Em seu voto, o Ministro Relator demonstra que essa interpretação restritiva (aplicar obrigação de fazer ou obrigação de pagar), que o Tribunal mineiro tem aplicado, está em discordância com o entendimento d STJ. Na hipótese, afirma o Relator que aplicam-se os princípios do poluidor-pagador, usuário-pagador e da reparação in integrum e, assim, chega-se a conclusão de que há a possibilidade de condenação cumulativa e simultânea em obrigações de fazer, não fazer e indenizar. Bem como, "em caso de dúvida ou outra anomalia técnico-redacional, a norma ambiental demanda interpretação e integração de acordo com o princípio hermenêutico in dubio pro natura". Pelo evidente antagonismo entre posições, admitiu a condenação em obrigação cumulativa ou conjuntiva. Recurso Especial parcialmente provido por unanimidade.

No Recurso Especial $\mathrm{n}^{\mathrm{o}} 1.180 .078 / \mathrm{MG}^{44}$ a relatoria também foi do Ministro Herman

\footnotetext{
${ }^{43}$ BRASIL. Superior Tribunal de Justiça. REsp 1198727/MG, Relator: Min. Herman Benjamin, Segunda Turma, julgado em 14/08/2012, DJ-e 09/05/2013.

44 BRASIL. Superior Tribunal de Justiça. REsp 1180078/MG, Relator: Min. Herman Benjamin, Segunda Turma, julgado em 02/12/2010, DJ-e 28/02/2012.
} 
Benjamin, tendo por recorrente o Ministério Público do Estado de Minas Gerais e por recorrido Rubens de Castro Maia. Cuida-se de Ação Civil Pública visando à responsabilização por danos ambientais causados pelo desmatamento de área de mata nativa. $\mathrm{O}$ Tribunal de origem entendeu que o art. $3^{\circ}$ da Lei 7.347/85 não permite a cumulação da reparação in natura com a indenização pelo dano ambiental.

Em seu voto, o Relator entendeu que não se deve interpretar o art. $3^{\circ}$ da Lei 7.347/85 restritivamente e destacou que a jusrisprudência firmada na Corte Superior é no sentido de que "[...] a necessidade de reparação integral da lesão causada ao meio ambiente permite a cumulação de obrigações de fazer e indenizar". O Relator também fundamenta sua decisão na Política Nacional do Meio Ambiente (Lei $\mathrm{n}^{\mathrm{o}}$ 6.938/81), principalmente no princípio do poluido-pagador presente no art. $4^{\circ}$ e na responsabilidade objetiva prevista no art. $14, \S 1^{\circ}$.

O Ministro ressalta que a cumulação de indenização com a recuperação ambiental são de providência ressarcitória civil e não configuram bis in idem já que não são "pena". "O pedido de obrigação de fazer cuida da reparação in natura do dano ecológico puro e a indenização visa a ressarcir os danos extrapatrimoniais, pelo que o reconhecimento de tais pedidos compreende as diversas facetas do dano ambiental."

E, sobre a hipótese, expressa:

\begin{abstract}
Aplica-se o princípio da reparação in integrum ao dano ambiental, que é multifacetário (ética, temporal e ecologicamente falando, mas também quanto ao vasto universo das vítimas, que vão do indivíduo isolado à coletividade, às gerações futuras e aos próprios processos ecológicos em si mesmos considerados). Se a restauração ao status quo ante do bem lesado pelo degradador for imediata e completa, não há falar, como regra, em indenização. A obrigação de recuperar in natura o meio ambiente degradado é compatível e cumulável com indenização pecuniária por eventuais prejuízos sofridos, até a restauração plena do bem lesado, assim como por aqueles de natureza extrapatrimonial, como o dano moral coletivo. Além disso, devem reverter à coletividade os benefícios econômicos que o degradador auferiu com a exploração ilegal de recursos ambientais, "bem de uso comum do povo", nos termos do art. 225, caput, da Constituição Federal, quando realizada em local ou circunstâncias impróprias, ou sem licença regularmente expedida ou em desacordo com os seus termos e condicionantes.
\end{abstract}

Diante isso, reconheceu a possibilidade de cumulação das obrigações. Recurso Especial parcialmente provido por unanimidade.

Por fim, o Recurso Especial n ${ }^{\circ} 1.114 .893 / \mathrm{MG}^{45}$, de relatoria do Ministro Herman Benjamin, tem por recorrente o Ministério Público do Estado de Minas Gerais e por recorrido Luiz Tito Ferreira. Trata-se de Ação Civil Pública por danos ao meio ambiente causados pelo recorrido, resultantes de garimpagem sem autorização. O Tribunal de origem entendeu que as condenações em restauração e indenização por danos causados ao meio ambiente não são cumuláveis, mas alternativas.

O Ministro traz à hipótese o princípio da reparação in integrum previsto no art. 225 da Constituição e na Lei 6.938/81, reconhecendo a possibilidade de cumulação das obrigações, resultando no parcial provimento do Recurso Especial por unanimidade.

c) Conclusão das análises de Responsabilidade Civil por danos ambientais

${ }^{45}$ BRASIL. Superior Tribunal de Justiça. REsp 1114893/MG, Relator: Min. Herman Benjamin, Segunda Turma, julgado em 16/03/2010, DJ-e 28/02/2012. 
Diante as duas primeiras decisões a cerca da prescrição, tem-se observado que a Corte Superior preserva o meio ambiente da forma como previsto na Constituição Federal, haja vista ser patrimônio não só desta geração mas também da geração vindoura. O Superior Tribunal de Justiça definiu que o bem ambiental trata de patrimônio público e desta forma abrangido pela imprescritibilidade.

Posteriormente, quanto à responsabilidade civil, percebeu-se que o STJ vem aplicando modalidades de reparação do dano ecológico embasadas no princípio in dubio pro natura. $\mathrm{Na}$ primeira decisão nota-se que, apesar de indeferir o pleito de elaboração de estudo de impacto ambiental, o Relator não deixou de prestar segurança aos que carecem de voz, decidindo pela realização de perícia técnica para apurar os danos ambientais e entendeu pelo ressarcimento dos danos além do pagamento pelo uso dos recursos hídricos. Já as decisões posteriores muito assemelham-se pois tratam de uma discordância entre a condenação cumulativa de cumprimento de obrigação de fazer ou não fazer e indenização em pecúnia. Porém, o Superior Tribunal de Justiça possui o entendimento de que, para o bem da presente e das próximas gerações, há sim a possibilidade de cumulação dessas obrigações. Preocuparam-se também, nessas decisões, em assegurar à coletividade a reversão dos benefícios econômicos que o degradador auferiu com a exploração ilegal de recursos ambientais, além de condenação a danos morais coletivos "bem de uso comum do povo", nos termos do art. 225, caput, da Constituição Federal.

As futuras gerações encontram-se protegidas pelo Tribunal Superior nessas decisões pois há a garantia do senso de igualdade. Ao condenar-se o degradador a restituir o meio ambiente ao status quo ante, tem-se a ideia de respeito ao acesso equânime intergerações.

\subsubsection{Competência}

Este subcapítulo tem como delimitação de tema decisões que envolvam a competência dos entes federativos para atuação nos processos e proteção ambiental. A Constituição Federal prevê em seu art. 23 e incisos a competência comum da União, dos Estados, do Distrito Federal e dos Municípios para a proteção e fiscalização do meio ambiente e seus recursos, estabelecendo uma comunhão no tocante a um meio ambiente ecologicamente equilibrado para as presentes e futuras gerações.

Paulo Affonso Leme Machado ${ }^{46}$, ao analisar o artigo supra, ensina:

A Constituição não quer que o meio ambiente seja administrado de forma separada pela
União, Estados, Distrito Federal e Municípios. É razoável entender-se que, na
competência comum, os entes federados devem agir conjuntamente. O art. 23 não exclui
qualquer ente federativo do exercício da competência. A “competência comum" é
aglutinadora e inclusiva, somando os intervenientes e não diminuindo ou tornando
privativa a participação.

Sendo assim, cumpre analisar a garantia às futuras gerações ao acesso ao meio ambiente ecologicamente equilibrado, observado o disposto na Carta Magna quanto à responsabilidade comum dos Entes Públicos, instrumento que garante maior proteção ao meio ambiente pois a competência comum inclusiva garante a fiscalização por meio da Administração Pública em alguma de suas esferas.

Após essa breve introdução ao tema, passa-se à análise dos julgados.

${ }^{46}$ MACHADO, Paulo Affonso Leme. Direito Ambiental Brasileiro, p. 181. 
O Recurso Especial $\mathrm{n}^{\mathrm{o}}$ 994.120/RS ${ }^{47}$ de relatoria do Ministro Herman Benjamin, tem por recorrente o Ministério Público do Estado do Rio Grande do Sul e por recorrido o Condomínio San Sebastian. A ação discute os limites da competência fiscalizatória municipal relacionada à perfuração de poço artesiano e sua exploração por particular. O Município de Erechim/RS autuou o recorrido e lacrou seu poço artesiano por inexistência de autorização e descumprimento da legislação estadual que veda a exploração dos recursos hídricos, pelo particular, naquela área. $\mathrm{O}$ Tribunal entendeu que a competência do Município refere-se somente à proteção da saúde pública e que a lacração do poço ocorreu devido a descumprimento das normas estaduais de exploração dos recursos hídricos, haja vista o comprovante de que a água é potável.

O Ministro Relator, em seu voto, entendeu que a hipótese trata sim de competência de fiscalização do Município. Por ser ente público, a competência do Município não se restringe às questões de saúde pública. Nesse sentido se expressa o Ministro:

Proteger os recursos hídricos, nos planos quantitativo e qualitativo, mais do que faculdade, é dever de todos os entes da federação: União, Estados, Distrito Federal e Municípios.

A Lei 9.433/97, adotada pelo TJ em suas razões de decidir, aponta claramente a competência dos municípios para a gestão dos recursos hídricos (art. $1^{\circ}$, VI) e para a "integração das políticas locais de saneamento básico, de uso, ocupação e conservação do solo e de meio ambiente com as políticas federais e estaduais de recursos hídricos" (art. $31)^{48}$. Os arts. $1^{\circ}$ e 31 , acima transcritos, devem ser interpretados em conformidade com a Constituição Federal, que fixa a competência comum dos municípios, relativa à proteção do meio ambiente e à fiscalização da exploração dos recursos hídricos (art. 23, VI e XI).

Ressalta que poços artesianos impactam na disponibilidade de recursos hídricos para "a população de hoje e de amanhã” e, sobre a Lei da Política Nacional de Recursos Hídricos ${ }^{49}$, defende que:

[...] significou notável avanço na proteção das águas no Brasil e deve ser interpretada segundo seus objetivos e princípios. Três são os seus objetivos dorsais, todos eles com repercussão na solução da presente demanda: a preservação da disponibilidade quantitativa e qualitativa de água, para as presentes e futuras gerações; a sustentabilidade dos usos da água, admitidos somente os de cunho racional; e a proteção das pessoas e do meio ambiente contra os eventos hidrológicos críticos, desiderato que ganha maior dimensão em época de mudanças climáticas.

Além disso, a Lei 9.433/97 apoia-se em uma série de princípios fundamentais, cabendo citar, entre os que incidem diretamente neste litígio, o princípio da dominialidade pública $^{50}$ (a água, dispõe a lei expressamente, é bem de domínio público), o princípio da

\footnotetext{
${ }^{47}$ BRASIL. Superior Tribunal de Justiça. REsp 994120/RS, Relator: Min. Herman Benjamin, Segunda Turma, julgado em 25/08/2009, DJ-e 27/04/2011.

${ }^{48}$ Art. 31. Na implementação da Política Nacional de Recursos Hídricos, os Poderes Executivos do Distrito Federal e dos municípios promoverão a integração das políticas locais de saneamento básico, de uso, ocupação e conservação do solo e de meio ambiente com as políticas federal e estaduais de recursos hídricos.

49 "A Política Nacional de Recursos Hídricos tem como objetivo central assegurar à geração presente e às futuras gerações a necessária disponibilidade de água, em quantidade e qualidade, e a utilização hídrica racional e integrada com vistas ao desenvolvimento sustentável" (VALADÃO, Maristela Aparecida de Oliveira. A (in)compatibilidade da privatização dos recursos hídricos com o direito fundamental humano de acesso à água. Revista de Direito Brasileira, Ano 3, vol.4, jan.-abril./2013, p. 272).

${ }^{50}$ Importante trazer o alerta de que "Ao tratar da água como um bem de domínio público, não significa dizer que a seja patrimônio do Estado, este se constitui mero administrador de um bem pertencente à coletividade." (VALADÃO, Maristela Aparecida de Oliveira. A (in)compatibilidade da privatização dos recursos hídricos com o direito fundamental humano de acesso à água. Revista de Direito Brasileira, Ano 3, vol.4, jan.-abril./2013, p. 271).
} 
finitude (a água é recurso natural limitado) e o princípio da gestão descentralizada e democrática.

Portanto, o entendimento do Relator foi no sentindo de que o Município detém a competência para fiscalizar a exploração de recursos hídricos em seu território no exercício de seu poder de polícia ambiental. Recurso Especial foi provido por unanimidade.

No Recurso Especial $\mathrm{n}^{\mathrm{o}} 1.071 .741 / \mathrm{SP}^{51}$, também de relatoria do Ministro Herman Benjamin, o Ministério Público do Estado de São Paulo foi o recorrente e a Fazenda do Estado de São Paulo, Marilda de Fátima Stankievski e Aparecido Silviero Garcia foram os recorridos. O processo versa sobre a omissão estatal, quanto ao seu poder de polícia ambiental em relação a danos causados por particular que invadiu o Parque Estadual Jacupiranga e sobre ele construiu imóvel e realiza exploração agrícola.

Por disposição constitucional e em razão do princípio da indisponibilidade do interesse público o Relator inicia fundamentando seu voto a favor da competência do Estado em tomar providências relevantes ao interesse público:

O dever-poder de controle e fiscalização ambiental (= dever-poder de implementação), além de inerente ao exercício do poder de polícia do Estado, jorra diretamente do marco constitucional (em especial dos arts. 23, VI e VII, 170, VI, e 225) e da legislação infraconstitucional, sobretudo da Lei da Política Nacional do Meio Ambiente (Lei 6.938/81, arts. $2^{\circ}$, I e V, e $6^{\circ}$ ) e da Lei 9.605/98 (Lei dos Crimes e Ilícitos Administrativos contra o Meio Ambiente).

O Relator fundamenta que o poder de polícia ambiental estatal é "de natureza vinculada, indisponível, irrenunciável e imprescritível" e, dessa forma, não se desincube do dever de "'fiscalização ambiental o Administrador que se limita a embargar obra ou atividade irregular e a denunciá-la ao Ministério Público e à Polícia”. E soluciona que a medida cabível à integridade do patrimônio público para a vida das presentes e futuras gerações, no presente caso de turbação ambiental, deve ser o desforço imediato:

Ninguém contesta, nem haverá de contestar, portanto, que a turbação e o esbulho do patrimônio do Estado são, no plano social, práticas das mais nocivas e que, se não combatidas pronta e firmemente, desequilibram as relações entre administrados e Administração, corroem a credibilidade do Estado e das suas instituições, e enfraquecem a força dissuasória da lei na sua nobre função de zelar por aquilo que pertence a todos, e às gerações futuras. É nessa visão de comunidade que respeita o pacto republicano radicado e radicalizado pela Constituição de 1988, mas também expresso em uma série de leis recentes, a ela posteriores e outras até anteriores, com ênfase para as de cunho urbanístico e ambiental -, que se insere, envolto num profundo conteúdo de justiça social e de proteção das gerações futuras, o desforço imediato a cargo da Administração Pública e as providências de auto-executoriedade a ele inerentes.

Segundo o Ministro, o entendimento do STJ é no sentido de que o Estado é solidariamente responsável por danos de terceiros ao meio ambiente, sendo essa posição reforçada pela Constituição e seu dever com a geração presente e vindoura.

Portanto, reconheceu o Ministro que a conduta omissiva ilícita do Estado de São Paulo colaborou para a degradação ambiental e, por consequência na hipótese está presente a sua

${ }^{51}$ BRASIL. Superior Tribunal de Justiça. REsp 1071741/SP, Relator: Min. Herman Benjamin, Segunda Turma, julgado em 24/03/2009, DJ-e 16/12/2010. 
responsabilização solidária subsidiária. O Recurso Especial foi provido por unanimidade.

O Agravo Regimental no Agravo de Instrumento $\mathrm{n}^{\circ}$ 973.577/ $\mathrm{SP}^{52}$, de relatoria do Ministro Mauro Campbell Marques, tem por agravante a Fazenda do Estado de São Paulo e por agravado Ministério Público do Estado de São Paulo. Discute-se no recurso a legitimidade do Estado de São Paulo para figurar no polo passivo de Ação Civil Pública que visa reparação dos danos ambientais decorrentes de loteamento irregular localizado em área de manancial. O Tribunal de origem entendeu que o Estado quando age por ação ou por omissão de seu poder de polícia ambiental pode figurar no polo passivo de ação civil pública.

Em seu voto, o Relator sustenta que o Tribunal de origem decidiu em conformidade com o entendimento do Tribunal Superior no sentido de "reconhecer a legitimidade passiva de pessoa jurídica de direito público para figurar em ação que pretende a responsabilização por danos causados ao meio ambiente em decorrência da sua conduta omissiva quanto ao dever de fiscalizar" baseando seu voto nos arts. 23, VI e 225 da Constituição Federal. O Agravo Regimental foi improvido por unanimidade.

O Recurso Especial $n^{0}$ 604.725/PR ${ }^{53}$ teve como relator o Ministro Castro Meira, sendo recorrente o Estado do Paraná e recorrido o Ministério Público Federal. Cuida-se, na origem, de Ação Civil Pública de responsabilidade por danos causados ao meio ambiente, proposta pelo Ministério Público Federal contra a União Federal, o Estado do Paraná (recorrente), o Município de Foz do Iguaçu e o IBAMA. Trata de construção de via pública na margem do Rio Paraná e do não cumprimento, por parte do Município, do Termo de Compromisso firmado com o IBAMA para proteção ao meio ambiente eis que a área na qual se projetou a construção trata-se de área de preservação permanente. O recorrente alega sua ilegitimidade para a causa haja vista sua participação limitada apenas ao financiamento da obra, e que a execução da obra ocorreu devido à licença do IBAMA e sob responsabilidade do Município de Foz do Iguaçu, não havendo, portanto nexo de causalidade.

Ao iniciar seu voto, o Relator dispõe que há a necessidade de o Estado figurar no polo passivo da ação, fundamentando com o art. 23, VI e 225 da Constituição Federal. Dispõe que é caso de responsabilidade solidária haja vista que o Estado não depende de convênio com a União ou Municípios para proteger o meio ambiente, fundamentando com o art. $14, \S 1^{\circ}$ da Lei $n^{\circ} 6938 / 81$ que "estabelece responsabilidade civil objetiva aos causadores do dano ambiental, implicando em solidariedade passiva entre os mesmos". Como o Estado tinha o dever de fiscalizar, "deveria ter requerido o Estudo de Impacto Ambiental e seu respectivo relatório, bem como até a realização de audiências públicas acerca do tema, ou até mesmo a paralisação da obra".

O Relator decidiu pela possibilidade de inclusão do Estado no polo passivo da Ação Civil Pública, baseando-se na responsabilidade objetiva e solidária, o que foi acompanhado pelos demais ministros, chegando-se ao improvimento do Recurso Especial por unanimidade.

Outros dois recursos foram interpostos pelo Instituto Estadual do Ambiente (INEA), um contra o Condomínio do Edifício Duque de Bragança (Recurso Especial no 1306093/RJ ${ }^{54}$ ) e outro contra o Condomínio do Edifício Centro Comercial Aminthas Gomes (Recurso Especial $\mathrm{n}^{\circ}$

\footnotetext{
${ }^{52}$ BRASIL. Superior Tribunal de Justiça. AgRg 973577/SP, Relator: Min. Mauro Campbell Marques, Segunda Turma, julgado em 16/09/2008, DJ-e 19/12/2008.

${ }_{53}$ BRASIL. Superior Tribunal de Justiça. REsp 604725/PR, Relator: Min. Castro Meira, Segunda Turma, julgado em 21/06/2005, DJ 22/08/2005, p. $202 .$.

${ }^{54}$ BRASIL. Superior Tribunal de Justiça. REsp 1.306.093/RJ, Relator: Min. Herman Benjamin, Segunda Turma, julgado em 28/05/2013, DJ-e 07/11/2016.
} 
1.296.193/RJ ${ }^{55}$ ), ambos sob a relatoria do Ministro Herman Benjamin. Esses julgados tratam da possibilidade e respectivas condições de utilização de água proveniente de fonte alternativa, para consumo e higiene humana, por condomínio situado em área urbana onde há abastecimento público.

O relator inicia sua explanação discorrendo sobre o regime jurídico das águas subterrâneas. O constituinte dispôs como bens da União "os lagos, rios e quaisquer correntes de água em terrenos de seu domínio, ou que banhem mais de um Estado, sirvam de limites com outros países, ou se estendam a território estrangeiro ou dele provenham, bem como os terrenos marginais e as praias fluviais" (art. 20, III, CF/1988). E são bens dos Estados "as águas superficiais ou subterrâneas, fluentes, emergentes e em depósito, ressalvadas, neste caso, na forma da lei, as decorrentes de obras da União" (art. 26, I, CF/1988).

Quanto à competência legislativa preceitua que cabe privativamente à União legislar sobre "águas, energia, informática, telecomunicações e radiodifusão" (art. 22, IV, CF/1988) e que compete, concorrentemente, à União, aos Estados e ao Distrito Federal elaborar leis sobre "florestas, caça, pesca, fauna, conservação da natureza, defesa do solo e dos recursos naturais, proteção do meio ambiente e controle da poluição". Atribui aos entes federados a competência comum para proteger o meio ambiente, combater a poluição e proceder ao registro, acompanhamento e fiscalização das concessões de direitos de pesquisa e exploração de recursos hídricos e minerais em seus territórios (art. 23, VI e XI, CF/1988).

Todas essas disposições se coadunam com o art. 225, caput, da Carta Magna e com a Política Nacional de Recursos Hídricos, que preocupa-se com a disponibilidade e qualidade da água como um recurso natural limitado, de domínio público e de valor econômico. Além disso, o caso em tela vincula-se à Lei que estabelece diretrizes nacionais para a política federal de saneamento básico. Acentuou, o Ministro Relator, ainda, que inexiste regime exclusivo abrangente para as águas subterrâneas.

O Relator entende que existem teses equivocadas sobre a diferente forma de expressão no dispositivo constitucional que não explicita as águas subterrâneas como bens da União e no dispositivo que cuida expressamente delas quando dispõe sobre os recursos hídricos estaduais. Discorre, primeiro, que "os fundamentos que justificam a dominialidade federal das águas superficiais recomendariam, com maior razão até, que não se deixem águas subterrâneas sob o domínio exclusivo dos Estados e Distrito Federal". Segundo, que não há omissão das águas subterrâneas no art. 20, mas técnica redacional eis que menciona "lagos, rios e quaisquer correntes de água", ou seja, não há nenhuma alusão ao fato de tais rios, lagos e correntes serem superficiais ou subterrâneos. Destaca o Ministro Relator:

O que se pretendeu, portanto, não foi excluir a União da dominialidade, mas assegurar que os Estados não seriam apartados das águas subterrâneas, de modo a fazer coincidirem as mesmas hipóteses fáticas de reconhecimento de sua dominialidade sobre águas de superfície.

O Estado, no entendimento do Relator, possui o domínio de certas águas subterrâneas, ampla concorrência para legislar sobre a tutela ambiental e o poder de polícia para prevenir danos aos recursos ambientais, fatos que refletem a intervenção imprescindível do Estado nessa seara. Por não se tratar, na hipótese, de águas subterrâneas federais, o Estado possui a propriedade dos recursos hídricos e, mesmo que na hipótese as águas subterrâneas não sejam de domínio do Estado.

55 BRASIL. Superior Tribunal de Justiça. REsp 1.296.193/RJ, Relator: Min. Herman Benjamin, Segunda Turma, julgado em 28/05/2013, DJ-e 07/11/2016. 
Dessa forma destaca o Relator:

[...] ainda assim não fica limitada a competência ambiental do Estado, seja para legislar sob tal ótica, seja para exercer seu poder de polícia para evitar degradação quantitativa (superexploração e exaustão da reserva) e qualitativa (contaminação dos aquíferos subterrâneos) de recurso natural tão precioso para as presentes e futuras gerações. A multiplicidade e a sobreposição de esferas de controle se justificam pela crescente escassez hídrica, que afeta milhões de brasileiros nas maiores cidades do País e incontáveis outros na zona rural, situação mais preocupante ainda diante de apavorantes previsões de agravamento ou até de calamidade pública, na esteira de incontestáveis mudanças climáticas antropogênicas que afetam o Planeta.

A instrução, do ponto de vista ambiental e sanitário, norteia-se para atentar-se sobre a exploração indistinta e desordenada de aquíferos em área urbana, tornando-se válida a preocupação do Estado quanto à perfuração de poços artesianos nessas áreas. Sendo assim, o Relator reforma a decisão do Tribunal a quo, o qual consignou na origem que, por não haver proibição quanto ao uso da água para consumo humano e higiene obtida de fontes alternativas, o Poder Executivo não poderia se escusado de deu poder regulamentar para criar tal proibição não prevista em lei. Nesse cenário, o Relator demonstra que o STJ possui entendimento diverso e informa que a Lei 9.433/97 condiciona a extração de água do subterrâneo à respectiva outorga. Conclui, diante do exposto, pelo provimento dos recursos para julgar improcedentes os pedidos iniciais.

O Recurso Especial no 1.410.732/RN ${ }^{56}$ de relatoria do Ministro Herman Benjamin, tem por recorrente Daniel Soares, por recorrido União e por interessado Município de Tibau do Sul. Tratase da construção de uma barraca, por particular, para fins comerciais na Praia de Cacimbinhas, Município de Tibau do Sul - RN, sem autorização as Secretaria do Patrimônio da União, empreendimento com precariedade higiênica e sanitária. O recorrente alega possuir alvará de licença concedido pelo Município, porém o acórdão recorrido esclarece:

A existência de convênio de cooperação técnica firmado entre a União e o Município, atribuindo competência a este para promover o planejamento e execução de ações para ocupação da orla marítima, não lhe conferiu o poder de ceder áreas de domínio da União, sendo ilegal o alvará de licença concedido ao barraqueiro, pelo que se mostra justa e razoável a condenação do ente municipal no custeio da demolição da construção e remoção dos materiais.

O Município, por sua vez, aduz a falta de interesse processual da União para requerer a desocupação da área por efeito da celebração de Convênio de Cooperação Técnica pelos entes, que atribui ao Município o planejamento e execução de ações em sua orla marítima. Reforça o fato de o empreendimento ser antigo na área e sua função social, eis que gera emprego, renda e colabora com o turismo local.

O Tribunal de origem conclui:

A ocupação das áreas de praia necessita de um minucioso estudo de impacto ambiental e só devem ser levadas a efeito após um planejamento estratégico dos poderes públicos que evite a ocorrência de danos ao meio ambiente, sendo mister a autorização da Secretaria do Patrimônio da União, quando se tratar de bem pertencente a esta unidade federativa.

\footnotetext{
${ }^{56}$ BRASIL. Superior Tribunal de Justiça. REsp 1.410.732/RN, Relator: Min. Herman Benjamin, Segunda Turma, julgado em 17/10/2013, DJ-e 13/12/2016.
} 
O Relator inicia com uma importante função do Direito Ambiental quanto à Zona Costeira:

Nosso Direito protege a Zona Costeira, território que alberga ecossistemas acossados por
atividades antrópicas diretas e, mais recentemente, por efeitos deletérios e implacáveis das
mudanças climáticas. Trata-se de espaço em que habitat de inúmeras espécies da flora e
da fauna ameaçadas de extinção - muitas delas endêmicas, por se encontrarem aqui e em
nenhum outro lugar do Planeta - coexiste com ricos sítios históricos e paisagens naturais
extraordinárias, exaltadas por brasileiros e estrangeiros. Um inestimável patrimônio
nacional e da humanidade que vem sofrendo constante e irrefreável degradação desde o
primeiro momento da colonização portuguesa, acentuada nas últimas décadas por conta
de desmatamento e especulação imobiliária, além de insensibilidade, desídia e
cumplicidade do Poder Público.

Quanto ao valor transcendental da Zona Costeira, o legislador no art. $3^{\circ}$ da Lei 7.661/98 prescreveu um microssistema jurídico próprio atinente ao tema que inclui, também, em seu art. $6^{\circ}$, $\S 2^{\circ}$, que a exploração dessas áreas implica Estudo Prévio de Impacto Ambiental.

Com relação ao tema da competência comum, informa o Ministro que, apesar de legitimados sob o manto do federalismo cooperativo ambiental e de políticas de descentralização, não há atribuição para órgão estadual ou municipal, "sponte sua, no âmbito de licenciamento e fiscalização ambientais, a qualquer título dispor, direta ou indiretamente, de áreas de domínio federal'. Na hipótese, apesar do domínio federal, a obrigação é solidária aos entes quanto à tutela do meio ambiente.

Ademais, a ocupação indevida dessa classe de espaço público e ecossistemas associados provocam a poluição paisagística e, nas palavras do Relator "nos ordenamentos contemporâneos, o elemento paisagístico - quer natural, quer artificial - ganha posição de bem jurídico culturalmente apreciado, legalmente individualizado, judicialmente garantido e temporalmente expandido ao agregar a perspectiva das gerações futuras".

Finalmente, nega provimento ao Recurso ao constatar ser ilícita a ocupação e determina a imissão sumária na posse do bem e o cancelamento de inscrições eventualmente realizadas.

Assim, conclui-se que o STJ, nesses quatro julgados, entendeu pela competência comum dos Entes quando trata-se do tema proteção ambiental, e sua omissão acarreta responsabilidade civil objetiva e solidária. Na primeira decisão, ao entender que o Município detém a competência para fiscalizar a exploração de recursos hídricos em seu território, assegurou a disponibilidade de recursos hídricos para a população de amanhã. Já na segunda decisão, ao reconhecer a conduta omissiva do Estado em relação à invasão ao Parque Estadual Jacupiranga e imputar-lhe a responsabilidade objetiva e solidária por danos causados por terceiros, assegurou a conservação com vistas a permitir que as futuras gerações também usufruam desse valor. Na terceira e na quarta decisão, concluiu que o Estado é parte legítima para figurar em ação que objetive a reparação de danos ambientais decorrentes de omissão de seu poder de polícia em loteamento irregular, e que, ao omitir sua competência, concorre para o dano ambiental.

Ao preocupar-se em atribuir a competência comum dos entes federativos, o STJ protege as futuras gerações da omissão e garante que todos são responsáveis por um meio ambiente ecologicamente equilibrado. Isso faz com que haja o mínimo de interferência na natureza da pessoa, o passado garante ao futuro nada menos do que recebeu das gerações passadas. 


\section{CONSIDERAÇÕES FINAIS}

O princípio da equidade intergeracional, abordado neste artigo, busca, através de solidariedade e inclusão, a preservação ambiental para as presentes e futuras gerações e ensina que o ser humano vive reciprocamente com a natureza. Nesse sentido, demonstrou-se a responsabilidade que a geração existente possui com a geração subsequente.

A partir disso, conforme a metodologia proposta, foram analisados os acórdãos proferidos pelo Superior Tribunal de Justiça (STJ) que possuíam a expressão "futuras gerações" em seu texto. Foram analisados 29 acórdãos, agrupados de acordo com a semelhança de assuntos, deixando-se de lado questões processuais.

A divisão ocorreu nos seguintes assuntos: patrimônio cultural, áreas de preservação permanente e reserva legal, responsabilidade civil por danos ambientais e competência. Sobre as decisões que envolvam o patrimônio cultural apurou-se que um dos instrumentos jurídicos que protege e conserva o patrimônio brasileiro é o tombamento. O STJ, em seus acórdãos, preocupa-se em defender o instituto do tombamento, por meio do qual o ordenamento jurídico garante que ninguém, por ação ou omissão, comprometa a herança coletiva e intergeracional do patrimônio ancestral e nada menos do que recebeu das gerações passadas seja deixado às próximas gerações.

A respeito das decisões que envolvam áreas de preservação permanente e de reserva legal verificou-se que, para que haja equilíbrio ambiental, essas reservas naturais precisam ser preservadas e o STJ reconhece em seus acórdãos que toda situação de supressão dessas áreas deve ser combatida com a condenação do proprietário do imóvel a restaurar a área ao estado ex ante.

Relativamente aos acórdãos que envolvem responsabilidade civil por danos ambientais e sua imprescritibilidade, o Superior Tribunal de Justiça definiu que o bem ambiental é patrimônio público e, dessa forma, abrangido pela imprescritibilidade. Quanto à responsabilidade civil, percebeu-se que o STJ vem aplicando modalidades de reparação do dano ecológico sempre embasadas no princípio in dubio pro natura.

Por fim, quanto às decisões que envolvem o tema da competência dos entes federativos na proteção ambiental, o Tribunal Superior demonstrou em seus acórdãos que a competência comum é instrumento que garante maior proteção ao meio ambiente pois, sendo inclusiva, de todas as formas se está garantindo a fiscalização ambiental por meio da Administração Pública em alguma de suas esferas.

Importante retomar o problema de pesquisa proposto: que parâmetros são adotados pelo Superior Tribunal de Justiça que permitam a proteção do meio ambiente para as futuras gerações?

Em resposta, a partir da análise das decisões mencionadas, parece ser possível traçar ao menos três parâmetros: 1) Prevenção da identidade das gerações vindouras, garantindo-lhes uma vida sem imposições passadas e impedindo que a presente geração interfira no patrimônio ambiental ou cultural, escolhendo qual merece ou não ser preservado. 2) Justiça solidária intergeracional, considerando os direitos fundamentais das futuras gerações e reconhecendo que a interferência das presentes gerações ameaça a expectativa de direitos das futuras.

Apesar desses parâmetros, percebe-se que a geração atual, ao tratar da matéria ambiental, está limitada a seus valores pessoais. Dessa forma, essa atuação não considera os interesses das futuras gerações eis que não compartilha dos mesmos valores e da mesma história de vida ${ }^{57}$. Para isso, é necessário reconhecer a vulnerabilidade ante a impossibilidade da geração futura em proteger seus interesses.

\footnotetext{
${ }^{57}$ SOUZA, Leonardo da Rocha de. A consideração dos ausentes à deliberação ambiental, passim.
} 
Algumas ações seriam necessárias para colocar esse propósito em prática: o dispêndio de recursos financeiros para realização de estudos na área ambiental e posterior ação do Estado ou de instituições privadas para sua implementação; a "tradução" das informações técnicas para que haja um entendimento da realidade ambiental, considerando que os saberes de cada participante variam de acordo com o grau de escolaridade ou história de vida; a frequência na deliberação de temas ambientais, haja vista a constante mudança de sua realidade; a pedagogia da imprensa, que ocorre por meio de campanhas de preservação, coletas seletivas e denúncia de desastres ambientais; e, a criação de instituições políticas que permitam a produção e retorno de críticas públicas.

Em vista disso, pode-se concluir que os participantes de um processo deliberativo, ao exprimirem opiniões racionais no tocante aos problemas ambientais, controlam o exercício do poder político na preservação de bens ambientais ou no combate a atitudes poluidoras, cabendo ao Estado agir, influenciado por opiniões públicas formadas por discursos racionais.

Apesar dos acertos das decisões do Superior Tribunal de Justiça na proteção das futuras gerações, o que preocupa são os casos que sequer citam as futuras gerações e aqueles que nem chegam ao Poder Judiciário. Assim, restam ainda alguns problemas a serem enfrentados:

a) que julgados do Superior Tribunal de Justiça deixaram de abrigar o direito das futuras gerações ao meio ambiente e não apareceram na pesquisa porque não contêm a expressão "futuras gerações"?

b) que julgados dos Tribunais de Justiça, Tribunais Regionais Federais e primeira instância deixaram de abrigar o direito das futuras gerações?

c) que situações de lesão aos direitos das futuras gerações ocorrem na esfera administrativa?

d) que situações de lesão jamais foram objeto de deliberação em qualquer instância decisória?

e) que situações de retrocessos legislativo lesaram o direito das futuras gerações ao meio ambiente?

Certamente, essas indagações são extremamente válidas e espera-se poder realizar outras pesquisas no futuro que tentem respondê-las.

\section{REFERÊNCIAS}

BEVILACQUA, Clóvis. Teoria Geral do Direito Civil. São Paulo: Servanda, 2007.

CARVALHO, Salo de. Como (não) se faz um trabalho de conclusão: provocações úteis para orientadores e estudantes de direito. 2. ed. São Paulo: Saraiva, 2013.

MACHADO, Paulo Affonso Leme. Direito Ambiental Brasileiro. São Paulo: Malheiros, 2014.

SCHIOCCHET, Taysa; LIEDKE, Mônica Souza. O direito e a proteção das gerações futuras na sociedade de risco global. Veredas do Direito, Belo Horizonte, v.9, n. 17.Janeiro/Junho de 2012.

SOUZA, Leonardo da Rocha de. A Consideração dos ausentes à deliberação ambiental: uma proposta a partir da ética do discurso de Jürgen Habermas. Rio de Janeiro: Lumen Juris, 2013.

VALADÃO, Maristela Aparecida de Oliveira. A (in)compatibilidade da privatização dos recursos hídricos com o direito fundamental humano de acesso à água. Revista de Direito Brasileira, Ano 3, vol.4, jan.-abril./2013. 